\title{
The forest has a story: cultural ecosystem services in Kona, Hawai'i
}

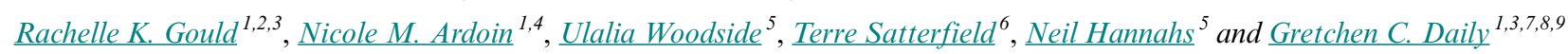

\begin{abstract}
Understanding cultural dimensions of human/environment relationships is now widely seen as key to effective management, yet characterizing these dimensions remains a challenge. We report on an approach for considering the nonmaterial values associated with ecosystems, i.e., cultural ecosystem services. We applied the approach in Kona, Hawai' $i$, using 30 semistructured interviews and 205 in-person surveys, striving to balance pragmatism and depth. We found spirituality, heritage, and identity-related values to be particularly salient, with expression of some of these values varying among respondents by ethnicity and duration of residence in Hawai' $i$. Although people of various backgrounds reported strong spirituality and heritage-related values, Native Hawaiians rated heritage connections as deeper, and lifetime residents portrayed ecosystem-identity connections as more integral to their wellbeing than did people from other backgrounds. The approach also proved useful in identifying concerns not addressed in survey and interview prompts, including postcolonial issues, access to ecosystems, and relationships between people of different ethnic backgrounds. Although understanding these nonmaterial dimensions of human-ecosystem relationships can be complex, emerging techniques eliciting qualitative and quantitative data provide feasible ways of deepening that understanding.
\end{abstract}

Key Words: environmental decision making; heritage; identity; mixed methods; semistructured interviews; spirituality; surveys; values

\section{INTRODUCTION}

Understanding how people value and use ecosystems is essential for efforts to make social-ecological systems sustainable (Kittinger et al. 2012). In particular, many argue that the intangible connections people have with the nonhuman world form the basis of a deep and respectful relationship necessary for sustainability (Clayton and Opotow 2003). Key challenges are how to characterize nonmaterial values related to ecosystems and integrate them into decision-making processes (Satz et al. 2013). We attempted to address the first of these challenges through a study focused on a specific ecosystem in Kona, Hawai'i, with the guiding question: What are the meanings and values of the forest to residents of Kona?

Nonmaterial values are relevant to many, if not most, land-use planning processes (Satterfield et al. 2013). Although the frame of ecosystem services is increasingly used in decision making (U. S. EPA Science Advisory Board 2009), cultural ecosystem services (CES), the focus of this study, remain infrequently studied and poorly understood, especially in comparison with more tangible ecosystem services (ES) such as water purification and climate stabilization (Millennium Ecosystem Assessment 2005). CES are defined as an ecosystem's contributions to the nonmaterial benefits that people derive from human-ecological relations (Chan et al. 2011). Our CES analysis is distinguished from an ES analysis more broadly by its focus on the nonmaterial aspects of human-nature relationships.

CES are often identified as important in ES analysis, but methods for characterizing them remain poorly developed (Schaich et al. 2010). Consider, for example, spirituality. Many people feel a spiritual connection with the nonhuman world (Taylor 2009a) and many religions relate to ecosystems in complex ways (Tucker and Grim 2001, Kellert and Farnham 2002). However, the idea of measuring that connection in ways analogous to measuring biophysical services such as water quality or carbon sequestration is, to many scholars, inappropriate (Meskell 2012) or offensive (McCauley 2006). Although we empathize with these concerns, we do not see these complications as insurmountable. They suggest instead the need to draw on past social research (Daniel et al. 2012) and develop creative, interdisciplinary approaches to characterizing these important values (Satz et al. 2013).

Of the few proposed typologies for CES, we used a suggested expansion of the Millennium Ecosystem Assessment's categories (Chan et al. 2012a). The typology we employed recognizes the importance of local context and collaboration with community members in the study area (Chan et al. 2012b). Paying attention to context and collaboration, we used mixed methods to address the following questions:

1. Which intangible values related to ecosystems, specifically which CES, are particularly salient, i.e., discussed frequently and in diverse ways, for Kona residents?

2. Do experiences of these values vary based on respondents' ethnicity, gender, time of residence, age, and level of education? If so, how?

\section{METHODS}

This study employed mixed methods to produce qualitative and quantitative data, designed so that the benefits and drawbacks of each method are complementary (Creswell and Clark 2007). Mixed methods are appropriate for "questions that call for reallife contextual understandings, multilevel perspectives, and cultural influences" (Creswell et al. 2011:4); all of these characteristics describe the questions in this study. We used a semistructured interpretive interview consisting of open-ended questions, combined with a survey consisting of mostly closedended items.

\footnotetext{
${ }^{1}$ Woods Institute for the Environment, Stanford University, ${ }^{2}$ Emmett Interdisciplinary Program in Environment and Resources, Stanford University, ${ }^{3}$ Center for Conservation Biology, Stanford University, ${ }^{4}$ Graduate School of Education, Stanford University, ${ }^{5}$ Land Assets Division, Kamehameha Schools, ${ }^{6}$ Institute for Environment, Resources, and Sustainability, University of British Columbia, ${ }^{7}$ Department of Biology, Stanford University, ${ }^{8}$ Global Economic Dynamics and the Biosphere, Royal Swedish Academy of Sciences, ${ }^{9}$ Stockholm Resilience Centre, University of Stockholm
} 
The interview included questions exploring respondents' forestrelated activities, perspectives on forest health and management, and forest-related values and meanings, which were loosely based on the conceptualization of CES we used (Chan et al. 2012a). Our semistructured interview format combined predefined questions with conversation-specific prompts, which encouraged respondents to use narrative and description to elaborate on the types of values sought (Patton 2002, Satterfield et al. 2013). We developed the interview protocol in collaboration with a multidisciplinary team (see Klain and Chan 2012 and Gould et al. 2014 for details). Appendix 1 provides the interview protocol.

The survey included closed-ended items regarding respondents' use of, perspectives on, and values related to the forest. Respondents scored answers by using binary terms, i.e., yes/no, and by using quantitative rankings, either relative, e.g., "arrange these options from most to least desired," or absolute, on a 1-to-5 scale. Research team members administered the surveys following a script. In some portions of survey administration, we also used hands-on and game-like interactions to facilitate respondent engagement (J. Puleston 2011, http://question-science.blogspot. com/2011/02/game-theory-turning-surveys-into-games.html). When we queried respondents about forest use, for example, we asked them to place cards labeled with various forest-related activities in one of three boxes labeled "Never done this," "Done in the past year," or "Done in the past month."

The survey and interview teams included a university $\mathrm{PhD}$ student, three university undergraduates, and two university undergraduates. Undergraduate team members conducted surveys, and the PhD student conducted all but one of the semistructured interviews.

\section{Participant selection}

We surveyed and interviewed residents of Kona, Hawai'i, during summer 2010. To reach a diversity of participants, in-person surveys were highly preferable to mail surveys. We used a convenience sample (Babbie 2009) because local experts indicated that visiting randomly selected houses would be extremely uncommon, and potentially culturally inappropriate, thus risking distorted findings.

For the surveys, we solicited participation from each passerby in public places, e.g., parks and grocery stores, throughout the day. We recruited people by asking, "Would you be willing to share your thoughts about mauka [upland] Kona?" Because Kona's forests are primarily above $\sim 800$ meters in elevation, use of the term mauka alerted participants to general survey content while minimizing response bias. Our pilot study suggested that mentioning forests encouraged some people to decline participation because they "had nothing to say about forests."

We surveyed only Kona residents, not tourists. Survey respondents $(n=205)$ completed the survey in an average of 23 minutes. Figure 1 provides details on our sample demographics and those reported in the U.S. Census. Post hoc analyses suggest that the sample was representative: Except for an underrepresentation of women $(61 \%[n=124]$ men, $39 \%[n=80]$ women), the demographics of survey participants closely match the census demographics of the study area (U.S. Census Bureau 2010), and our data on nonrespondents exhibited no patterns that we anticipated would bias interpretation.
In addition to these surveys, we interviewed 30 Kona residents. Interviews lasted from one-and-a-half to four hours. We purposefully selected individuals thought to possess a diversity of relationships with Hawai'i's forests. The goal of this selection approach based on divergent cases was to acquire a breadth of perspectives in a small sample size, rather than to obtain a statistically representative sample (Patton 2002). Table 1 provides details on the interview sample, which is diverse in terms of ethnicity, age, and gender.

Table 1. Characteristics of interviewees.

\begin{tabular}{|c|c|}
\hline Characteristic & Interview sample \\
\hline $\begin{array}{l}\text { Number of } \\
\text { Respondents }\end{array}$ & 30 individuals \\
\hline Gender & $\begin{array}{l}13 \text { women } \\
17 \text { men }\end{array}$ \\
\hline Age & 26 to $72($ mean $=52) \mathrm{yrs}$ \\
\hline Ethnicity & $\begin{array}{l}13 \text { Native Hawaiian } \\
17 \text { not Native Hawaiian }\end{array}$ \\
\hline Time in Hawai'i & $\begin{array}{l}6 \text { recent arrivals }(<10 \mathrm{yrs}) \\
5 \text { long-time residents }(>10 \mathrm{yrs} \text {, not whole life }) \\
19 \text { lifetime }\end{array}$ \\
\hline $\begin{array}{l}\text { Relationship to } \\
\text { Forest } \\
\text { [categories used for } \\
\text { selection] }\end{array}$ & $\begin{array}{l}7 \text { work in land management } \\
6 \text { have recognized cultural position related to } \\
\text { forest or land (e.g., hula practitioner, cultural } \\
\text { specialist) } \\
2 \text { work on Hawaiian cultural issues related to } \\
\text { forest or land, but without a formal "cultural } \\
\text { expert" position } \\
2 \text { have artistic relationship (painter, } \\
\text { photographer) } \\
1 \text { has volunteer relationship (restoration } \\
\text { volunteer) } \\
3 \text { have organizational relationship (part of an } \\
\text { organization with forest relationship (hiking or } \\
\text { hunting)) } \\
9 \text { have no formal relationship with forest (yet } \\
\text { most of these people interact with the forest in } \\
\text { various ways) }\end{array}$ \\
\hline
\end{tabular}

\section{Data analysis}

We conducted interviews and surveys concurrently, with the goal of acquiring similar information in two distinct ways. This is one recommended format for mixed-methods research (Creswell and Clark 2007). Specifically, we used preliminary findings from interview data to structure analysis of survey data. We choose this approach because of the nature of our survey; survey items covered a breadth of topics, and we did not want to "cherry pick" survey data (Gilbert 2008). Thus, we used interview data to suggest CES that were particularly rich or informative and ran statistical analyses only on that small selection of survey items. Conclusions from these first two analytical steps then informed iterative exploration of the entire data set. We used a modified grounded theory, i.e., an inductive, approach, with a priori categories/codes coupled with prominent emergent categories/ codes (Pickett et al. 1999, Maxwell 2005).

\section{Interview analysis}

We transcribed interviews verbatim and coded them using the qualitative software NVivo 10 (QSR International, http://www. qsrinternational.com/products_nvivo.aspx). We categorized the 
Fig. 1. Comparison of demographic information for the census vs. the survey sample.

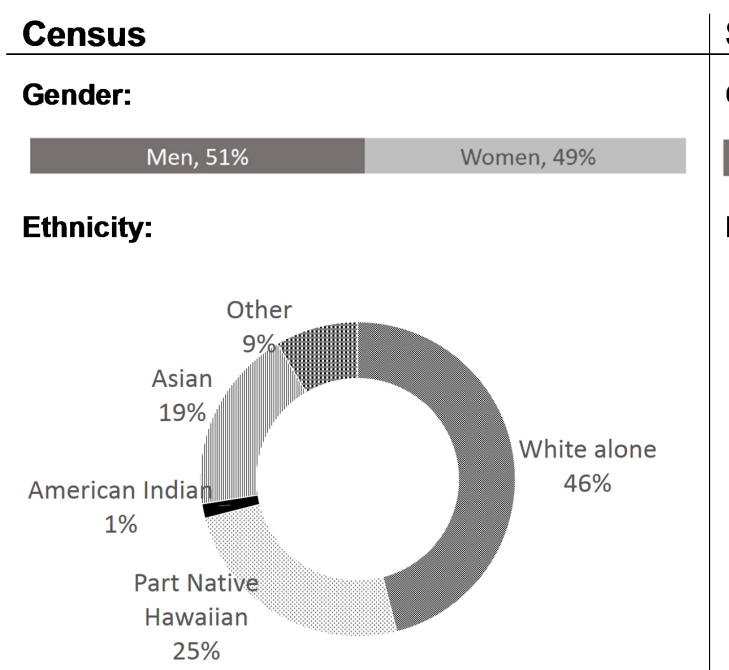

Survey Sample

Gender:

Men, $61 \%$

Ethnicity:

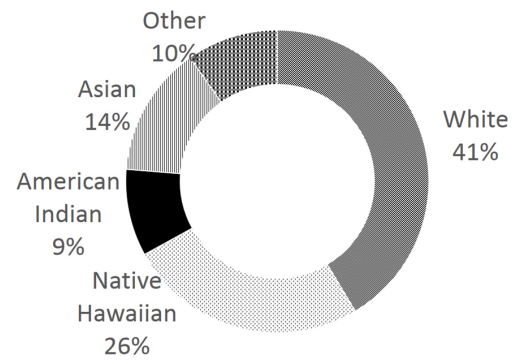

*Ethnicity used is that which respondent reported 'most identifying with'

Age:

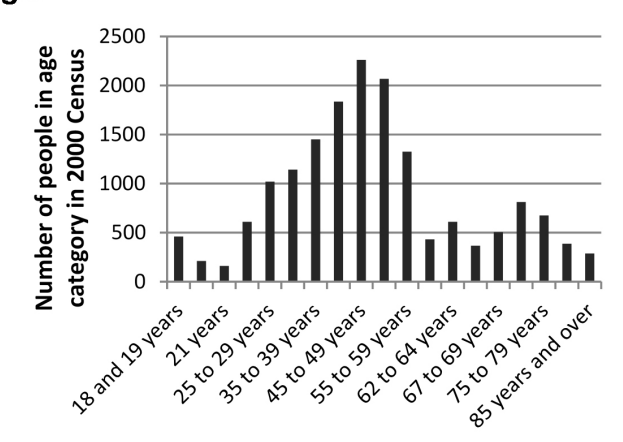

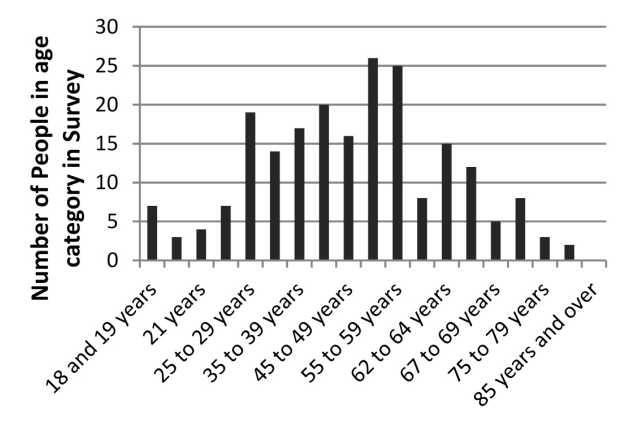

transcripts based on themes (Maxwell 2005), targeting the particular CES of interest, e.g., education, heritage, but also remaining open to emerging themes and patterns. The research team developed codes through an iterative process. We coded with a hierarchical structure, developing 268 themes that were grouped into 33 parent themes. An example of a parent theme was threats; two subthemes within threats were pollution and development. We emphasize that the categories stemmed from our coding into these bins, rather than absolute, pre-existing categories in the data.

\section{Survey analysis}

We analyzed survey data using the Statistical Package for the Social Sciences, version 21 (IBM 2012). We measured most CES constructs, e.g., spirituality, using one item and statistically analyzed single survey items. Although this one-item approach is less robust than measuring a single concept with multiple questions, it was necessary to allow us to cover all desired topics and avoid respondent burnout. To explore differences based on respondent background, we analyzed respondent groups along four dimensions of interest: age, ethnicity, level of education, and residence time. Appendix 2 provides details on how we divided the sample. We used nonparametric Wilcoxon-Mann Whitney tests (Mann and Whitney 1947) to assess whether observed differences in responses between groups were significant. We tested three questions, spirituality, heritage, and identity, along these four dimensions of respondent background, for a total of
12 tests. With a $95 \%$ confidence level $(P=0.05)$, the Bonferroni correction, which accounts for the testing of multiple relationships (Samuels and Witmer 2003), dictated that $P$ values $<0.004$ were significant. We report $P$ values before the Bonferroni correction (Nakagawa 2004), but label as significant only those that fell within the corrected Bonferroni range (Fig. 2).

\section{Reporting back}

To help ensure that our work was productive and cooperative (Shirk et al. 2012) and to make it more visible to local decision makers, we shared our study findings with the community in a locally resonant manner. The lead researcher worked with a local hula school, Hālau o ka Hāliko, to develop a show that included original performances of hula (Hawaiian dance/spiritual ceremony in which many movements mimic elements of nature), chanting, and music based on study findings. Appendix 3 and the Research Speaks website (http://www.researchspeaks.org) provide details, including photographs and video, of the performance.

\section{RESULTS}

Salient values and respondent background

In our interviews, respondents were free to discuss topics they felt were relevant to human-nature relationships. We identified values as particularly salient in Kona based on relative prevalence and 
Fig. 2. Results of comparisons of survey respondents grouped by different characteristics of their backgrounds. Significance values ( $\mathrm{p}$-values) are provided before the Bonferroni correction. Main findings are in italics. $* * * \mathrm{p}<$ 0.0008 , significant at a $1 \%$ error level with the Bonferroni correction. $* * p<0.004$, significant at a $5 \%$ error level with the Bonferroni correction. ${ }^{*} \mathrm{p}<0.008$, significant at a $10 \%$ level with the Bonferroni correction.

\begin{tabular}{|c|c|c|c|c|c|c|c|c|}
\hline & \multicolumn{2}{|c|}{ Ethnicity } & \multicolumn{2}{|c|}{ Residence Time } & \multicolumn{2}{|c|}{ Age } & \multicolumn{2}{|c|}{ Level of Education } \\
\hline Question & \multicolumn{2}{|c|}{$\begin{array}{l}\text { Native Hawailan vs. } \\
\text { not Native Hawaiian }\end{array}$} & \multicolumn{2}{|c|}{$\begin{array}{l}\text { Longtime residents } \\
\text { (>65\% of life) vs. } \\
\text { relatively new arrivals } \\
\quad(<65 \% \text { of life })\end{array}$} & \multicolumn{2}{|c|}{$\begin{array}{l}\text { People over } 50 \text { vs. } \\
\text { People } 50 \text { or over }\end{array}$} & \multicolumn{2}{|c|}{$\begin{array}{l}\text { People with high school } \\
\text { education vs. those with } \\
\text { postgrad degree }\end{array}$} \\
\hline \multirow{3}{*}{$\begin{array}{c}\text { "I have a } \\
\text { spiritual } \\
\text { connection with } \\
\text { the forest" }\end{array}$} & \multicolumn{2}{|c|}{ No difference } & \multicolumn{2}{|c|}{ No difference } & \multicolumn{2}{|c|}{ No difference } & \multicolumn{2}{|c|}{ No difference } \\
\hline & \multicolumn{2}{|c|}{$\begin{array}{c}U=3195.0 \\
p=0.03\end{array}$} & \multicolumn{2}{|c|}{$\begin{aligned} U & =4188.5 \\
p & =0.049\end{aligned}$} & \multicolumn{2}{|c|}{$\begin{array}{c}U=4504.0 \\
p=0.253\end{array}$} & \multicolumn{2}{|c|}{$\begin{array}{c}U=4084.5 \\
p=0.020\end{array}$} \\
\hline & $\begin{array}{l}\text { Native } \\
\text { Hawaiians: } \\
\text { Median: } 5 \\
\text { MR: } 114\end{array}$ & $\begin{array}{l}\text { Non- } \\
\text { Native } \\
\text { Hawaiians } \\
\text { : Median: } \\
4 \text { MR: } 95\end{array}$ & $\begin{array}{l}\text { Longer term } \\
\text { residents: } \\
\text { Median: } 4 \\
\text { MR: } 92\end{array}$ & $\begin{array}{l}\text { More recent } \\
\text { arrivals: } \\
\text { Median: } 5 \\
\text { MR: } 107\end{array}$ & $\begin{array}{l}\text { People over } \\
\text { 50: } \\
\text { Median: } 4.5 \\
\text { MR: } 105\end{array}$ & $\begin{array}{l}\text { People } \\
\text { under } 50: \\
\text { Median: } 4 \\
\text { MR: } 96\end{array}$ & $\begin{array}{l}\text { With 'higher' } \\
\text { Education: } \\
\text { Median: } 5 \\
\text { MR: } 109\end{array}$ & $\begin{array}{l}\text { Without } \\
\text { 'higher' } \\
\text { Education: } \\
\text { Median: } 4 \\
\text { MR: } 91\end{array}$ \\
\hline \multirow{3}{*}{$\begin{array}{l}\text { "There are } \\
\text { places in the } \\
\text { forest that } \\
\text { remind you of } \\
\text { past events that } \\
\text { are important to } \\
\text { both you and } \\
\text { your } \\
\text { community." }\end{array}$} & \multicolumn{2}{|c|}{$\begin{array}{c}\text { Native Hawaiians } \\
\text { report higher levels of } \\
\text { connection to past } \\
\text { events }\end{array}$} & \multicolumn{2}{|c|}{ No difference } & \multicolumn{2}{|c|}{ No difference } & \multicolumn{2}{|c|}{ No difference } \\
\hline & \multicolumn{2}{|c|}{$\begin{array}{c}U=2514.5 \\
p<0.0005^{\star \star \star}\end{array}$} & \multicolumn{2}{|c|}{$\begin{array}{l}U=4134.0 \\
p=0.077\end{array}$} & \multicolumn{2}{|c|}{$\begin{array}{l}U=4352.0 \\
p=0.245\end{array}$} & \multicolumn{2}{|c|}{$\begin{array}{c}U=4720.0 \\
p=0.743\end{array}$} \\
\hline & $\begin{array}{l}\text { Native } \\
\text { Hawaiians: } \\
\text { Median: } 5 \\
\text { MR: } 124\end{array}$ & $\begin{array}{l}\text { Non-Native } \\
\text { Hawaiians: } \\
\text { Median: } 4 \\
\text { MR: } 91\end{array}$ & $\begin{array}{l}\text { Longer term } \\
\text { residents: } \\
\text { Median: } 4.5 \\
\text { MR: } 105\end{array}$ & $\begin{array}{l}\text { More recent } \\
\text { arrivals: } \\
\text { Median: } 4.0 \\
\text { MR: } 92\end{array}$ & $\begin{array}{l}\text { People over } \\
50: \\
\text { Median: } 4 \\
\text { MR: } 103\end{array}$ & $\begin{array}{l}\text { People } \\
\text { under 50: } \\
\text { Median: } 4 \\
\text { MR: } 94\end{array}$ & $\begin{array}{l}\text { With } \\
\text { 'higher' } \\
\text { Education: } \\
\text { Median: } 4 \\
\text { MR: } 99\end{array}$ & $\begin{array}{l}\text { Without } \\
\text { 'higher' } \\
\text { Education: } \\
\text { Median: } 4 \\
\text { MR: } 101\end{array}$ \\
\hline \multirow{3}{*}{$\begin{array}{l}\text { "I identify } \\
\text { strongly with } \\
\text { the Hawaiian } \\
\text { forest." }\end{array}$} & \multirow{2}{*}{\multicolumn{2}{|c|}{$\begin{array}{c}\text { Hawaiians reported a } \\
\text { stronger identification } \\
\text { with the forest. } \\
\qquad \begin{array}{c}U=2970.5 \\
D=0.007^{\star}\end{array}\end{array}$}} & \multicolumn{2}{|c|}{ No difference } & \multicolumn{2}{|c|}{ No difference } & \multicolumn{2}{|c|}{ No difference } \\
\hline & & & \multicolumn{2}{|c|}{$\begin{array}{c}U=4695.5 \\
p=0.434\end{array}$} & \multicolumn{2}{|c|}{$\begin{array}{c}U=4288.5 \\
p=0.063\end{array}$} & \multicolumn{2}{|c|}{$\begin{array}{c}U=4744.0 \\
p=0.431\end{array}$} \\
\hline & $\begin{array}{l}\text { Native } \\
\text { Hawaiians: } \\
\text { Median: } 5 \\
\text { MR: } 118 \\
\end{array}$ & $\begin{array}{l}\text { Non-Native } \\
\text { Hawaiians: } \\
\text { Median: } 4 \\
\text { MR: } 95\end{array}$ & $\begin{array}{l}\text { Longer term } \\
\text { residents: } \\
\text { Median: } 4.5 \\
\text { MR: } 97\end{array}$ & $\begin{array}{l}\text { More recent } \\
\text { arrivals: } \\
\text { Median: } 5 \\
\text { MR: } 103\end{array}$ & $\begin{array}{c}\text { People over } \\
\text { 50: } \\
\text { Median: } 5 \\
\text { MR: } 108\end{array}$ & $\begin{array}{c}\text { People } \\
\text { under } 50: \\
\text { Median: } 4 \\
\text { MR: } 94\end{array}$ & \begin{tabular}{|} 
With 'higher' \\
Education: \\
Median: 5 \\
MR: 105
\end{tabular} & $\begin{array}{l}\text { Without } \\
\text { 'higher' } \\
\text { Education: } \\
\text { Median: } 4 \\
\text { MR: } 99\end{array}$ \\
\hline
\end{tabular}

inter-respondent variation of interviewee responses. The following analysis combines results from surveys and interviews, with a focus on three CES: spirituality, heritage, and identity. The need for brevity dictated a focus on three CES if we were to do justice to the depth of our data. Thus, we focused on spirituality and heritage because they stood out as the most often-discussed CES (Table 2). Of the two next-most-discussed CES, bequest and identity, striking variation in respondents' discussions of identity led us to more deeply analyze this topic; bequest was discussed more similarly by respondents. We used identity as an example of a CES that may vary substantially among individuals.

\section{Spirituality}

Spirituality was mentioned by every interviewee. There were a total of 393 mentions across all interviewees, with an average of 13 mentions per interviewee. For the survey's spirituality item, "I have a spiritual connection with the forest," differences between respondents of different background were not significant when the Bonferroni correction was applied (Fig. 2).

Interview data on spiritual relationships with ecosystems did not demonstrate patterns by ethnicity. All but four respondents replied in the affirmative to the question about spirituality, i.e., experiencing ecosystem-inspired feelings related to "entities larger than yourself." Of these four, two were white women, relatively new arrivals, and two were Native Hawaiians, one woman and one man.

Table 3 demonstrates the diversity of spirituality subthemes addressed by respondents. One expression of spirituality, animism, the idea of the physical world as animated by a soul or spiritual/metaphysical properties, was mentioned by a majority of interviewees. Interviewees' discussions of animism exhibited no strong patterns, but non-Native Hawaiians referred to the concept slightly more frequently than Native Hawaiians. 
Table 2. Themes addressed by at least half of interview respondents (including responses to specific questions). Rows in italics are themes that were not specifically prompted in interviews. We elaborate on the theme of perspective in Gould et al. (2014).

\begin{tabular}{|c|c|c|c|}
\hline Theme Name & Theme Description & \# Interviewees & \# Mentions \\
\hline Spiritual & $\begin{array}{l}\text { Forces larger than oneself, connecting to something bigger, energies, and/or } \\
\text { established religion. }\end{array}$ & 30 & 393 \\
\hline Heritage & $\begin{array}{l}\text { References to traditional practices related to forest. References to kupuna or } \\
\text { ancestral connection. Places important because of past events or stories. } \\
\text { Meanings of place names. }\end{array}$ & 30 & 385 \\
\hline Native Species & Native plant or animal species mentioned & 29 & 201 \\
\hline Identity & Identity as it relates to ecosystems. Mention of "who I am," "part of me," etc. & 29 & 144 \\
\hline Bequest & Value of ecosystems for future generations & 29 & 106 \\
\hline Artistic & $\begin{array}{l}\text { Producing art that is inspired by the ecosystem; or enjoying art produced by } \\
\text { others that is related to the ecosystem }\end{array}$ & 26 & 81 \\
\hline Access & Issues related to access to ecosystems in Kona & 25 & 114 \\
\hline Learn About Place & When a place teaches the respondent about itself (winds, rains, cycles, etc.) & 25 & 99 \\
\hline Healthy Forest & Answer to prompt about what makes for a healthy forest & 25 & 58 \\
\hline Perspective & $\begin{array}{l}\text { Talking about gaining perspective on one's place, seeing where one fits. "Putting } \\
\text { things back in perspective". }\end{array}$ & 25 & 52 \\
\hline Healthy Community & Answer to prompt about what makes for a healthy community & 25 & 44 \\
\hline Ethnic Diversity & Discussions of differences between ethnicities, or relationships between ethnicities & 24 & 131 \\
\hline Ceremonial & Specific mention of ceremony, including prayer & 24 & 85 \\
\hline Learn About Life & When a place teaches bigger life lessons & 23 & 91 \\
\hline Caring & Caring, expressing care toward land and getting something in return. & 22 & 91 \\
\hline Development as Threat & Development as a threat -- residential or commercial development & 21 & 78 \\
\hline Water & Water as related to ecosystems & 20 & 70 \\
\hline Invasive Species & $\begin{array}{l}\text { Invasive plant or non-ungulate animal species mentioned; ungulates were in a } \\
\text { different category. }\end{array}$ & 21 & 69 \\
\hline Indigenous Knowledge & $\begin{array}{l}\text { Traditional Ecological Knowledge or Indigenous Knowledge related to } \\
\text { management or conservation }\end{array}$ & 20 & 54 \\
\hline Aesthetic & $\begin{array}{l}\text { Beauty, the pleasing aspect of an ecosystem. Aesthetic: "nature of beauty, art, } \\
\text { and taste, and with the creation and appreciation of beauty." }\end{array}$ & 20 & 53 \\
\hline Change in Values & Changes in social values, including property rights and land ownership, over time & 20 & 49 \\
\hline $\begin{array}{l}\text { Different Views of } \\
\text { Resources }\end{array}$ & $\begin{array}{l}\text { Differences in view about ecosystems (resources) in particular from people with } \\
\text { differing backgrounds, including but not limited to ethnicity. }\end{array}$ & 20 & 48 \\
\hline Postcolonial & Hawai'i as a postcolonial society & 19 & 89 \\
\hline Cultural Practices & $\begin{array}{l}\text { Cultural practices -- not specifically spiritual practices -- that are related to an } \\
\text { ecosystem }\end{array}$ & 19 & 87 \\
\hline Stories & Use of story personal stories, societal histories, or cultural stories (mo'olelo) & 19 & 61 \\
\hline Science & $\begin{array}{l}\text { Science as important in making decisions about land use, either personal decisions } \\
\text { or societal decisions }\end{array}$ & 19 & 54 \\
\hline Restoration & Restoration of Hawaii's ecosystems & 19 & 46 \\
\hline Holistic Value & $\begin{array}{l}\text { Value of ecosystems as general, complete, or rich; an overarching description of } \\
\text { value that does not fit other CES categories }\end{array}$ & 19 & 36 \\
\hline
\end{tabular}

Many respondents also addressed the sacredness of ecosystems' physical support of life. A lifetime resident of Japanese ancestry felt, for instance, "that the forest is a very spiritual place for a number of reasons, but one reason is that you know that the person [before you] to this land utilized the forest to survive, to protect themselves, in all aspects of life." Touching on a similar theme, a Native Hawaiian woman shared that "... whether invoking ancient gods or revering the creator that we are taught in the new Word, Hawaiians maintain an active, dynamic, interactive relationship with deity, and what deity has provided for us, to sustain us."

A long-time resident of European heritage spoke more broadly of the spiritual character of ecosystems' abundance:

What I learned by study somewhat of the trees and nature, is the incredible bountiful nature of it ... nobody looks at an orange tree just pouring forth seeds galore, right? ... and you only need one seed to generate another tree ... I mean nature is so obvious that it's a god because it's just this endless pouring forth of life. Imean, it's incredible.

\section{Heritage}

Survey respondents who self-identified as Native Hawaiian reported higher levels of agreement with the statement: "There are places in the forest that remind you of past events that are important to both you and your community" $(P<0.0005$; Fig. $2)$. This result remained significant after the Bonferroni correction. We found that interview respondents mentioned heritage with essentially the same high frequency as they did spirituality. Heritage was mentioned in every interview for a total of 385 times among all respondents. Table 4 shows the different aspects, or subthemes, of heritage that interviewees discussed.

Although people of all ethnicities talked both frequently and infrequently about heritage, those who mentioned heritage with exceptional frequency ( $\geq 18$ mentions) were all Native Hawaiian 
Table 3. Spirituality subcodes. A division of the 395 references to spirituality into subthemes, with an example provided for each subtheme.

\begin{tabular}{|c|c|c|c|}
\hline Theme & People & Mentions & Description of Subtheme \\
\hline General Spirit & 22 & 51 & $\begin{array}{l}\text { Spirit or spiritual well-being, } \\
\text { without reference to any } \\
\text { particular practice or belief } \\
\text { system }\end{array}$ \\
\hline Animism & 20 & 79 & $\begin{array}{l}\text { Personified nature, or other } \\
\text { comments implying that } \\
\text { nonhuman entities have a soul } \\
\text { conscience }\end{array}$ \\
\hline $\begin{array}{l}\text { Overarching } \\
\text { Hawaiian } \\
\text { Spirituality }\end{array}$ & 19 & 72 & $\begin{array}{l}\text { Hawaiian spirituality generally } \\
\text { (not prayers, ceremony, or } \\
\text { animism) }\end{array}$ \\
\hline
\end{tabular}

Example

"Well, it's this feeling spiritually inside. Makes you feel good, and everything else in the world is kinda out of balance. It might not really be in balance, but it has the appearance that way." "The process of making a koa canoe was very involved. The Kahuna Kâlai Wa'a [master canoe builder] would make sure that the tree cooperated with the canoe-making, that the tree agreed. The Kahuna Kalai Wa'a would say, today you are a tree, tomorrow you become a man. They would only cut the tree after meditation and a good deal of nonverbal communication."

"It's the essence. It's those things that you can't touch or see, but you can feel. You know? It's that ... feeling of love and peace and godliness. ... And especially with our culture, it represents our gods, and deities, and things attached to the specific plants and trees, and it carries that essence of just amazing, how amazing our ancestors were that came before us. That came up with these traditions and practices that got passed down to us. ... It gives us little glimpses of how amazing they were. And connected to the universe."

Hawaiian ceremony $\quad 15 \quad 37 \quad$ Ceremonies associated with traditional Hawaiian spirituality

"Yes, just like even when they go pick maile, like a lot of people they neglect to tie the ti leaf, but they go in there just culturally, you tie the ti leaf to thank the gods, for making this that you, that you harvested from the forest."

$\begin{array}{lccl}\text { Mo'olelo (spiritual) } & 12 & 25 & \begin{array}{l}\text { Spiritual aspects of deity/ } \\ \text { ancestors or past leaders (or } \\ \text { Discussion of deity/ancestors/past } \\ \text { leaders in a spiritual context) }\end{array} \\ \text { Hawaiian Prayer } & 12 & 23 & \text { Hawaiian prayer specifically }\end{array}$

"When the big thunder and lightning comes, and it's in the season of Lono, I'll acknowledge him. Or at other times of the year,

$\begin{array}{llll}\text { Hawaiian Prayer } & 12 & 23 & \text { Hawaiian prayer specifically }\end{array}$ him."

"And it's not always about communicating in words. Words can get in the way, but they can also help.... The purpose of the chant is that now we're all more closely psychologically connected. The chant helps to get us into the mindset of the forest."

"...whether invoking ancient gods or revering the Creator that we

are taught in the new world, Hawaiians maintain an active, dynamic, interactive relationship with deity, and what deity has provided for us, to sustain us. So, I, as an ardent practitioner of the ancient ways and a recent convert to Christianity, I find my relationship changed a little, the vocabulary that I use and the practices that I engage in and with, which is just like a physical vocabulary, may be different, but the relationship is the same." "It's just-I'm very sensitive to the energy. Good, bad, whatever, and so I feel really good energy in [the forest]. It's very energizing. It just feels really good. It just feels like a place you could -- it's hard to shut down. Everything you wanted to know kind of opens up if you just sit there long enough and just enjoy it. You think, wow, this is how the world should be. It's a beautiful place, instead of the other things you experience. So it's kind of a nice getaway and a regenerating kind of feeling."

"Dark Green

Religion”

Not Spiritual

7

Hula

5

Christian
More amorphous energies or forces
14

15

9

Sacredness of ecological processes and the Earth or awe and a feeling of 'something larger than yourself' from purely physical properties.

Comments about a lack of spirituality as respondent thinks about it; or, 'we don't think about those things'

Spiritual aspects of hula

Christianity (solely)
"Spiritually, I don't believe in heaven so therefore - and I don't want to say something like "heaven on earth." But that without actual dialogue, if you wanna call it that, or exposure within a natural (a nonhuman or a natural) system, I'm incomplete. My children are incomplete. I believe that."

"Not being born and raised here, I wouldn't say I have a spiritual connection. I have an emotional connection. I love the forest. I've always loved forest."

"As years went on, and I as years go on, and I deepen my knowledge and experience of hula, I deepen my respect and knowledge of the forest, and my experience of the forest as a really really sacred place."

"And it fits right down to even the Christian belief, where God freely gave, freely gave his whole Garden -- Earth -- for us to use and live on." 
Table 4. Heritage subcodes. A division of the 385 references to heritage into subthemes, with an example provided for each subtheme.

\begin{tabular}{lccl}
\hline \hline Theme & People & Mentions & Description of subtheme \\
\hline $\begin{array}{l}\text { Practices Related to } \\
\text { Resources and Place }\end{array}$ & 28 & 99 & $\begin{array}{l}\text { Resource-or place-related heritage-based } \\
\text { practices. Includes general comments (e.g., } \\
\text { "what happened here before") and }\end{array}$ \\
& & $\begin{array}{l}\text { mentions of specific activities (e.g., } \\
\text { gathering lei materials, medicines, feathers; } \\
\end{array}$ & \\
& & \\
& & \\
& &
\end{tabular}

Mo'olelo
Shared, collective stories of Hawaiian heritage. Includes both "mythical" stories and more certain historical facts, because in many cases distinctions between the two aren't important.

Ideas or beliefs based on or drawing from heritage.

Stories and histories of the respondents' general).

Ceremony based on Hawaiian heritage.

Mentions of 'aumakua (deified ancestor who can assume the form of animals, plants, rocks, clouds, etc). family (as opposed to Hawaiian culture in

Example

"... what is important for the forest or the landscape, or why is it important to protect it. Cause it's not just about me, it's about what happened here before, and is it worth protecting those activities and things in the landscape that need to be protected, otherwise you couldn't have those same activities, you couldn't -- that history couldn't live on, because it would be too altered."

"The land is connected. Papa and Wâkea, you heard of them, right? Okay, it's all in the connection. Father Sky, who was that? Wâkea. Papa, Mother Earth. And the forest is like a path to heaven, yeah. It's not just a forest to go get timber, it means so much more to people ...."

"Taking the Hawaiian descriptor kama'âina, child of the land, very seriously to be able to know my homeland as well as I know my family."

"And then, I have to bring my dad's family in, because they got a whole lot of history up here. On this side, where my mom folks' house is. All the way to first lava flow from here. Yeah. And you know, there were a lot of people, a couple of generations up, that he talks about. He talks about that. Who lived up here, made their living. With the taro, and hunting, all that kind of stuff."

"Interviewer: all this work that you do with the ki' $\mathrm{i}$ [carved wooden poles], how does the forest relate to that? How does the forest influence...?]

Connect. ... This connect[s] because the heiau, ... heiau, all the ki'i, the sculptures, ... when they came, the spirit, the ki' $\mathrm{i}$, what they came is from Polynesia. All the ki'i, that came from the canoe too."

"In our family, the "aumakua is the pueo [Hawaiian owl]. I've had many incidents with the pueo; ... everybody has had experiences. ... We don't question it, we just - it's almost like stop, and take a good look at your life, yourself, those around you and see whether you are being pono [balanced, righteous] with one another. That's the first thing you do. Are you right with yourself? If not, then you're not being right with the others and all of that."

Discussions of names having significance or "People named the place Opihi hale. It was not meaning, related to heritage because of Hawaiian words and underlying meaning. Opihi hale, it was some stupid haole people out there to say oh it must be Opihi hale [house of shellfish]. But Ope is when you [makes carrying motion] and Hale is when you're you're coming together."

Discussions of heritage explicitly mentioned "Then I would say that we have to give an exalted non-Native Hawaiian heritage. place to the cultural practices that integrate into their practices preservation. Well, when I was in Wisconsin, when the native peoples, which are very small now in numbers, but when they came and talked about their philosophy, it was much better than my philosophy in terms of how people and natural places interact, ... as a human and our needs can culturally interact with the forest or with the natural environment, right?"

"Now, that's designed probably more for Hawaiians; outside of picnicking with family, no." 


\begin{tabular}{|c|c|c|c|}
\hline Hula Heritage & 3 & 9 & $\begin{array}{l}\text { Mentions of hula more holistically, not it } \\
\text { terms of prayer, or collecting, or the myt } \\
\text { associated with it. }\end{array}$ \\
\hline $\begin{array}{l}\text { Practices Related to } \\
\text { Prayer }\end{array}$ & 2 & 2 & $\begin{array}{l}\text { Prayer as it relates to, or is drawn from, } \\
\text { heritage. }\end{array}$ \\
\hline
\end{tabular}

"The connection between hula and the forest is huge. Because, Laka is the goddess, the patron goddess of hula, that we quote-unquote worship, or whatever. I don't really use that word; I just honor her. I don't worship her. But like, she, she is the forest. .... And her movements, which are the movements of the forest, and the movements of the leaves, and the wind through the trees, ... are what we aspire to mimic and imitate in our dance."

"You have to mâlama, take care, the forest. Before you take anything from the forest, you need to pray. You need to ask. You need to ask to take. And take only what you need. Because ...

otherwise, it's no good to you. And I believe that."
(Fig. 3). Native Hawaiian respondents were more likely to discuss heritage in personal terms, whereas respondents of other ethnicities often reflected on the importance of ecosystems for Native Hawaiian heritage-based values, even if they did not feel as personally involved as they observed Native Hawaiians to be. For instance, one Native Hawaiian respondent in his fifties described how he has:

\begin{abstract}
always been interested in Hawaiian issues and Hawaiian lands ... and now [in my current occupation] I get to use it on a regular basis, and it's kind of neat that all those years of studying this stuff is not a total waste [laughs]. It never, never was a waste because it helped me form my own identity but ... it's kinda cool that I can ... share it.
\end{abstract}

Alternatively, a white recent arrival in her fifties discussed her zeal for learning the heritage-based stories of the land:

I want to go through the whole story and walk the land with the story. There's a story ... in all the land. You just don't always know what it is, and it's great when you start hearing these different stories, and you can go and walk that area and get a sense of what it was about.... So it makes you want to protect and share it.

Fig. 3. Number of times each respondent discussed heritage.

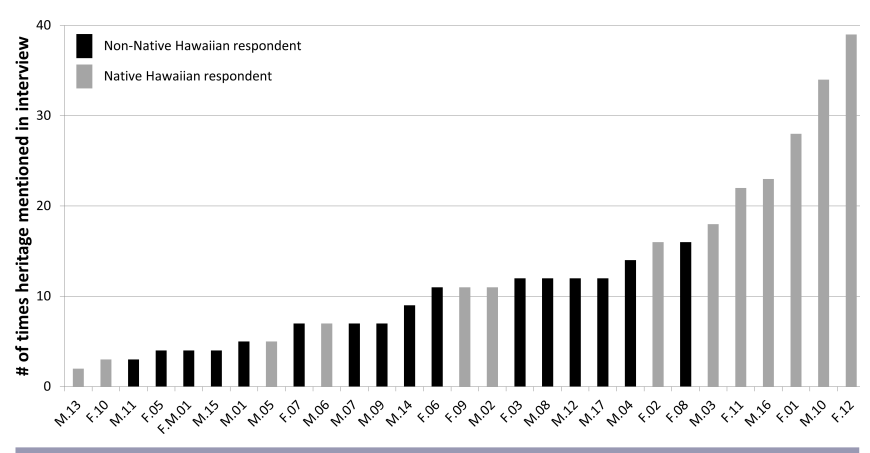

\section{Identity}

Although Native Hawaiian respondents reported, on average, higher levels of agreement with the identity survey item "I identify strongly with the Hawaiian forest" than other ethnicities, the difference was not significant after the Bonferroni correction (Fig. 2).
In interviews, the concept of identity as connected to ecosystems seemed to resonate more often, and more deeply, with kama'âina, translated as "child of the land," indicating someone of any ethnicity born in Hawai'i, than with more recent arrivals. When people were speaking of identity, interview responses clustered more by length of residence than by ethnicity; people who had lived in Hawai'i their entire lives spoke of identity in similar ways regardless of ethnicity.

Kama'âina frequently discussed how the islands' ecosystems are intertwined with conceptions of identity and self-esteem, personally and collectively. One 72-year-old Hawaiian woman reflected on how:

... there's great joy in being able to go [into a forest]. I can
remember the smell, the sounds, and ... wow, I can ... just
sit down with this fern, and put it together, and haku [weave]
a lei [woven arrangement of vegetation], and feel
beautiful again. Smell good. And feel good. You know?
And just really owning who I am.

Another Hawaiian woman in her forties expressed related sentiments on a societal level. When asked how Hawaii's ecosystems relate to identity, she explained how "understanding what it is to be Hawaiian" could address vexing concerns facing Kona's youth. Her description integrally relates that understanding to Kona's ecosystems:

Understanding what it is to be Hawaiian, what it is to have
the aloha spirit. What aloha really means to us. As soon
as our children understand these things, they can move
forward positively. Understanding the values of our ocean,
the cultural values of our mountains, the value of our
traditions and our practices.

In addition to connecting identity to self-esteem, interviewees also addressed associations among identity, activities, and social relationships. For many respondents, identity was intertwined with cultural practices dependent on ecosystems, such as collecting food or lei making. Respondents discussed identity as affected by and formed through social interactions, which are in turn affected by and related to those cultural practices. Figure 4 conveys one way of categorizing conceptions of the relationships among identity, ecosystems, and practices; the quotations suggest the role social relations can play.

Intermingling of spirituality, heritage, and identity

As evidenced by quotes provided, respondents' discussions of spirituality, heritage, and identity often overlapped. Figure 5 shows comments coded as all combinations of these three values. 
Fig. 4. Identity-ecosystem relationships, as discussed by interview respondents.

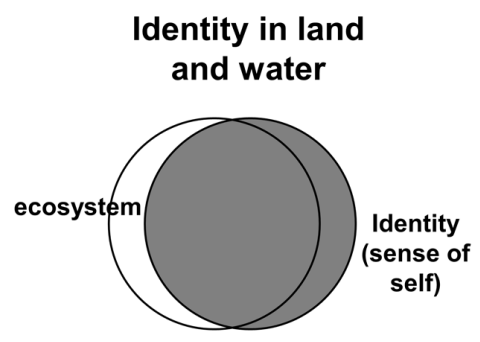

"[My] identity [and the] ecosystem are kinda one and the same. For me, anyway, the ecosystem is what has made my identity, is what has made me who I am." (Hawaiian man, 30s, lifelong resident)

"Because Hawaiians without land cannot be Hawaiians. You have to be connected to the land. You can't go to Nevada and really be Hawaiian Until you can relate to this mountain, that ocean. Unil you can relate to this mountain, that ocean, pauses], in Hawai'i." (Hawaiian man, 50s, lifelong resident)

"For us as Hawaiians I think who we are is directly linked to Hawai'i. Like I said earlier, it's made us who we are today. We are a product of this land. If we lose [land] to someone else ... we've lost a piece of our own identity. It's gone. Every time we lose a species it's a loss of our identity." (Hawaiian man, 30s, lifelong resident)

"You know, it's your identity. It's your heritage. you gotta take a step back once in awhile ... and reconnect. We have been disconnected with our culture... . Sometimes we gotta reconnect, yeah, and it's these places that are the places that we can do that. We can't reconnect in Walmart, or McDonalds or wherever, right? But you can do it here [outdoors]." (Hawaiian man, early 70s, lifelong resident)

\section{Identity in land and water, expressed through practices}

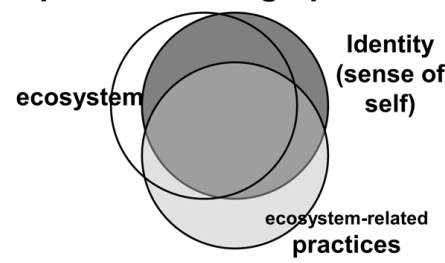

"...the ability to farm or to fish, or to gather or to make food together, to hunt. It's hard to explain who you are but it's the practices that go with it, the interaction with family. .... observing a place and weather and times to go hunting and times to go fishing." (Japanese man, 40s, lifelong resident)

"So, we need to stand up and be willing to be identified as the Hawaiian selves that we are. We need to claim to be our true selves. Keiki o ka 'ãina. Child of the land. And that's basically where I come out of. The land took care of us. My dad I come out of. The land took care of us. My dad
fished. My Tutu Lady [grandmother] taught us how fished. My Tutu Lady [grandmother] taught us how
to go get [lists five other harvested items to go get [lists five other harvested items
(shellfish, seaweed)]. And all the things we grew up with, that brought us joy. We did it with our own hands. We knew how." (Hawaiian woman, 70s, lifelong resident)

“... identity, would be almost the stepping stones of what made you what you are now ... I can identify with the forest in certain areas, more so than other areas, because there's historical significance there for me.... Because I went up there with my classes. And we learned about the there with my classes. And we learned about the
forest. And we pointed out plants. And I go to forest. And we pointed out plants. And I go to
harvest there. So, it helps kinda develop that personal identity of [pause] it being an important area, and kind of adding to what I know." (White woman, 20s, lifelong resident)

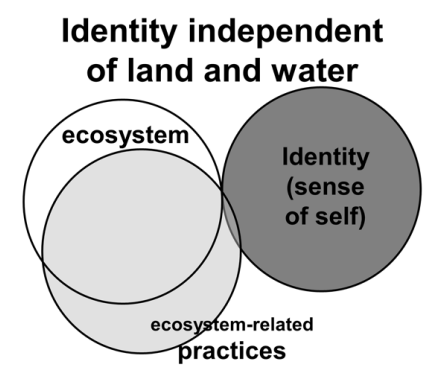

"I don't really feel that identity is necessarily tied too much to places. It would be places where I volunteer, places where I do things ... where we paddle, where we snorkel, where we run, where we live. But that's not that tied personally. [Interviewer: Not as much, central to your identity.] No." (White man, 60s, 5-year resident)

"Well, I would expect a link [between places and people, as that link relates to identity], and my definition of a link would be a requirement that you personally had some history of some personal relationship with a place, which I don't really I go to these places, I appreciate them, I really. I $m$, but I places, like it's "home" like respect them, but I don't feel like it's "home," like own it. You know, I feel like it's acceptable for me to be there because I respect it, but I don't feel like I own it, which I would have to feel to identify with it personally." (White woman, 50s, 3-year resident)
Fig. 5. Graphical representation of the overlap between the three interview themes discussed in this study. Size of circle is approximately proportional to the number of comments coded as each theme. Numbers indicate the number of statements coded with that combination of topics.

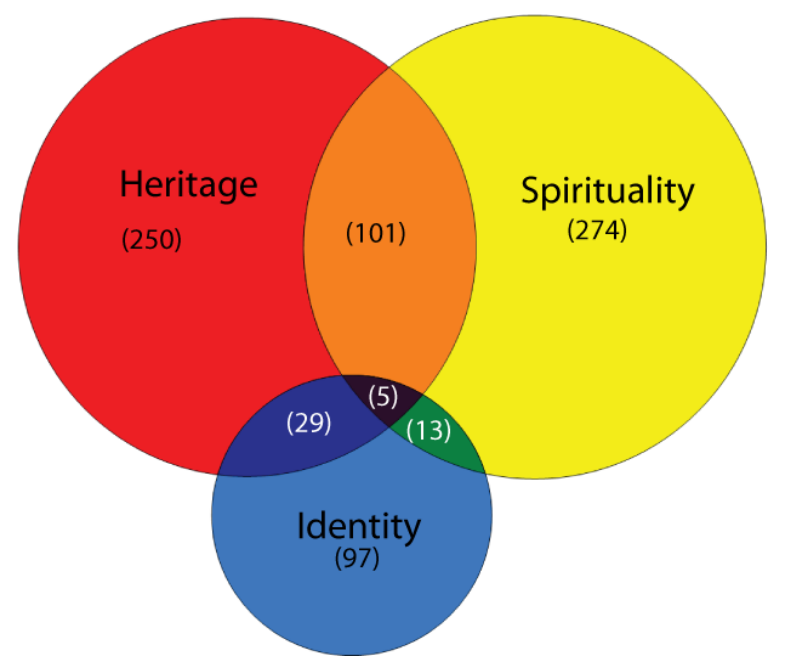

\section{Unanticipated issues}

Interview and survey respondents frequently mentioned nonprompted themes. Table 2 demonstrates the frequency with which interviewees discussed the most common emerging themes. We elaborate on four themes that are particularly relevant to and informative for CES studies. We focused on these four themes because each suggests a unique consideration for future CES elicitation frameworks and analyses, perhaps more than other frequently mentioned emerging themes. These considerations are the interaction of CES with specific biophysical characteristics (native species); how socio-political context affects CES (access); how human diversity affects CES (ethnic diversity); and the importance of considering deep-seated emotional reactions to CES analysis (postcolonial issues). To demonstrate the relationships among our various results, Figure 6 presents the overlap between these four unprompted themes and our focal CES: spirituality, heritage, and identity.

Native species

In interviews, native species were the most commonly discussed nonprompted topic (Table 2). The majority of native species mentioned were plants (Fig. 7). Native species were most frequently discussed in conjunction with references to heritage and spirituality (Fig. 7). 
Fig. 6. Interactions between three most common CES addressed and emerging themes. We provide counts of comments coded as each pair of themes, as well as sample quotations.

\begin{tabular}{|c|c|c|c|c|c|c|c|}
\hline & & \multicolumn{6}{|c|}{ Emerging Themes } \\
\hline & & \multicolumn{2}{|c|}{ Access } & \multirow{2}{*}{$\frac{\text { Ethnic Diversity }}{33 \text { phrases }}$} & \multirow{2}{*}{$\begin{array}{c}\text { Native Species } \\
39 \text { phrases }\end{array}$} & \multicolumn{2}{|c|}{ Postcolonial } \\
\hline & & \multicolumn{2}{|c|}{8 phrases } & & & \multicolumn{2}{|c|}{19 phrases } \\
\hline & & $\%$ heritage: $2 \%$ & $\%$ access: $7 \%$ & \begin{tabular}{l|l|}
$\%$ heritage: $9 \%$ & $\%$ ethnic div: $25 \%$ \\
\end{tabular} & \begin{tabular}{|l|l|}
$\%$ heritage: $10 \%$ & $\%$ native spp: $19 \%$ \\
\end{tabular} & $\%$ heritage: $5 \%$ & $\%$ postcol.: $21 \%$ \\
\hline & & \multicolumn{2}{|c|}{$\begin{array}{c}\text { "Here's a very interesting question that } \\
\text { we are going to be dealing with ... :we } \\
\text { wanna restore the access, ... but ... you } \\
\text { have to ... accommodate and encourage } \\
\ldots \text { bikers and joggers. [But they] are not } \\
\text { part of that place. You see, you can't } \\
\text { have a paved road. You can't ride your } \\
\text { bicycle on the King's Trail..." }\end{array}$} & $\begin{array}{c}\text { "...the first time I was young, and I } \\
\text { approached the mountain in a Western } \\
\text { way. I thought, I'm going to hike up that } \\
\text { mountain. The second time, later, I was } \\
\text { with a group of Hawaiians, and I learned } \\
\text { about the history of the mountain, what } \\
\text { the mountain means, and I felt much } \\
\text { more connected to it." }\end{array}$ & $\begin{array}{l}\text { "...the point to take away [from the } \\
\text { geneologies] is that they all connect us } \\
\text { back, to our lands and the native biota, } \\
\text { and everything ... shares this common } \\
\text { ancestry, and therefore, you know, we } \\
\text { are family, and there's certain } \\
\text { responsibilities that people have to the } \\
\text { land, to take care of the land, and then } \\
\text { also the land has to the people, to take } \\
\text { care of us." }\end{array}$ & \multicolumn{2}{|c|}{$\begin{array}{l}\text { "It made such an impression on me that } \\
\text { that's how it used to be here before } \\
\text { Captain Cook came and ruined it all, but } \\
\text { that's why, that's all I can say. It was jus } \\
\text { like a glimpse back into time." }\end{array}$} \\
\hline & \multirow[b]{3}{*}{ : } & \multicolumn{2}{|c|}{6 phrases } & 8 phrases & 8 phrases & \multicolumn{2}{|c|}{6 phrases } \\
\hline & & $\%$ identity: $4 \%$ & $\%$ access: $5 \%$ & \begin{tabular}{l|l}
$\%$ identity: $6 \%$ & $\%$ ethnic div: $25 \%$ \\
\end{tabular} & \begin{tabular}{l|l|}
$\%$ identity: $5 \%$ & $\%$ native spp: $4 \%$ \\
\end{tabular} & $\%$ identity: $4 \%$ & $\%$ postcol.: $21 \%$ \\
\hline Uు & & \multicolumn{2}{|c|}{$\begin{array}{l}\text { "Beginning in this century [a landowner] } \\
\text { has adjusted ... access policies to get intc } \\
\text { these higher lands, so it's become more } \\
\text { difficult for us to access them. But they } \\
\text { remain an important part of who we } \\
\text { are." }\end{array}$} & $\begin{array}{c}\text { "... on paper I am of Japanese ancestry. } \\
\text { As far as my beliefs, you know, being } \\
\text { born and raised here, being connected to } \\
\text { the land and to the people, I have a lot of } \\
\text { beliefs in the traditional Hawaiian ways: } \\
\text { taking care of the land, providing, and } \\
\text { treating people well.... I think that } \\
\text { people that have those values, no } \\
\text { matter, you know, where they're from ... } \\
\text { I consider them, you know, in spirit, } \\
\text { they're Hawaiians." }\end{array}$ & $\begin{array}{l}\text { "...the Hawaiian birds, as long as they } \\
\text { exist (at least to me) the Hawaiian stuff } \\
\text { exists. As they die out, the less and less } \\
\text { Hawaiian things you have, the less and } \\
\text { less Hawaiian things you have, that's - I } \\
\text { don't want that to happen. I want things } \\
\text { to be Hawaiian. So the birds are } \\
\text { important as far as my own identity is } \\
\text { concerned. ... if they cannot survive I } \\
\text { don't know if I can survive, I don't know } \\
\text { if my kids can survive." }\end{array}$ & \multicolumn{2}{|c|}{$\begin{array}{l}\text { "...because of the colonialism that has } \\
\text { come our way, you have to learn, for the } \\
\text { sake of your next generations and } \\
\text { yourself, how to live the double identity } \\
\text { We cannot get out of being American. } \\
\text { We cannot get out of being Hawaiian, } \\
\text { but we know that Hawaiian means this } \\
\text { and that. Being American means being } \\
\text { this and that .... How do you handle } \\
\text { [these identities]? What do you glean to } \\
\text { teach the next generation?" }\end{array}$} \\
\hline & \multirow[b]{3}{*}{ 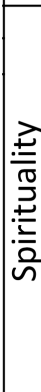 } & \multicolumn{2}{|c|}{2 phrases } & 14 phrases & 27 phrases & \multicolumn{2}{|c|}{9 phrases } \\
\hline & & $\%$ spirituality: $1 \%$ & $\%$ access: $2 \%$ & \begin{tabular}{|l|l|}
$\%$ spirituality: $4 \%$ & $\%$ ethnic div: $11 \%$ \\
\end{tabular} & \begin{tabular}{|c|c|}
$\%$ spirituality: $7 \%$ & $\%$ native spp: $13 \%$ \\
\end{tabular} & $\%$ spirituality: $2 \%$ & $\%$ postcol.: $10 \%$ \\
\hline & & \multicolumn{2}{|c|}{$\begin{array}{l}\text { "The place for me on the mountain that } \\
\text { is important, that spiritual thing about } \\
\text { being up, something about being up } \\
\text { high. Things that I gather from the fores } \\
\text { are important, like maile and koa. And... } \\
\text { just the time spent in the forest. So it's } \\
\text { not necessarily taking something from it, } \\
\text { but just having access to it." }\end{array}$} & $\begin{array}{l}\text { "Through [Westerners'] eyes, the hula } \\
\text { [was] sensual, sexual, provocative. They } \\
\text { did not see it from our eyes, as I am one } \\
\text { with the land, and all of me that is } \\
\text { created by Ke akua [ } \text { dieties] and all of } \\
\text { this that is created by Ke akua. " }\end{array}$ & $\begin{array}{l}\text { "...Laka is the goddess, the patron } \\
\text { goddess of hula ... is the forest.... From } \\
\text { the high trees, the top of the high koa } \\
\text { trees, and the 'ie'ie vines, to the bottom, } \\
\text { the ferns.... And her movements, which } \\
\text { are the movements of the forest, and the } \\
\text { movements of the leaves, and the wind } \\
\text { through the trees, and the branches ... } \\
\text { are what we aspire to mimic and imitate } \\
\text { in our dance. To be like that." }\end{array}$ & \multicolumn{2}{|c|}{$\begin{array}{l}\text { "1820s, missionaries came in and } \\
\text { changed everything. So a lot of our } \\
\text { people converted to Christianity. Today a } \\
\text { lot of our people are Christian. But } \\
\text { spirituality is all over us. We cannot } \\
\text { explain, but we're very spiritual people. } \\
\ldots \text { you're raised a Christian, and then } \\
\text { there's traditions and ... ceremonies of } \\
\text { the Hawaiian. You still participate. } \\
\text { Sometimes it kinda outweighs ... the } \\
\text { Christianity, because people like to say } \\
\text { they were Hawaiians before they were } \\
\text { Christians [laughs]. " }\end{array}$} \\
\hline
\end{tabular}

Fig. 7. References to native species and intangible values.

\begin{tabular}{|c|c|c|c|c|c|c|c|c|c|c|c|c|c|c|}
\hline & 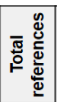 & $\begin{array}{l}\frac{0}{\bar{m}} \\
\frac{0}{5} \\
\frac{5}{4}\end{array}$ & 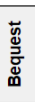 & 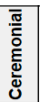 & 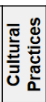 & 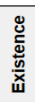 & 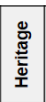 & 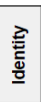 & $\begin{array}{l}\frac{\underline{u}}{\underline{w}} \\
\stackrel{\underline{E}}{\underline{E}}\end{array}$ & $\begin{array}{l}\frac{0}{\bar{E}} \\
\frac{0}{\underline{m}} \\
\frac{\underline{x}}{\underline{x}}\end{array}$ & & & 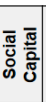 & $\begin{array}{l}\text { 㥯 } \\
\frac{\bar{z}}{\bar{n}}\end{array}$ \\
\hline strial Birds & 50 & 3 & 4 & 0 & 1 & 0 & 14 & 2 & 2 & 0 & 1 & 5 & 1 & 14 \\
\hline Native Marine Spp. & 5 & 1 & 1 & 0 & 1 & 0 & 1 & 0 & 1 & 0 & 0 & 0 & 1 & 1 \\
\hline Native General & 9 & 1 & 2 & 0 & 0 & 0 & 1 & 2 & 1 & 1 & 0 & 2 & 0 & 1 \\
\hline Native Bats, Insects & 4 & 0 & 1 & 0 & 0 & 0 & 1 & 0 & 0 & 0 & 0 & 0 & 0 & 2 \\
\hline Native Plants & 154 & 8 & 5 & 9 & 4 & 3 & 25 & 4 & 5 & 0 & 2 & 7 & 1 & 17 \\
\hline
\end{tabular}

Kama'âina respondents tended to mention native species more frequently than more recent arrivals (Fig. 8). These mentions often referred to spirituality, heritage, and/or identity. Spirituality, for example, infused one 45-year-old Native Hawaiian man's description of ki'i (log carvings) for a heiau (temple):

We needed those ['ōhi'a (Meterosideros polymorpha)] logs for the temples. Because the function of the 'ōhi' a is to collect water. ... [Similarly] the ki $i$ can collect the energies. The ki i are like this [gets into high crouch]. They're ready to spring. They're ready to take action. They're ready to go on the heiau.
Fig. 8. Average number of times native species mentioned per interviewee, by interviewee background.

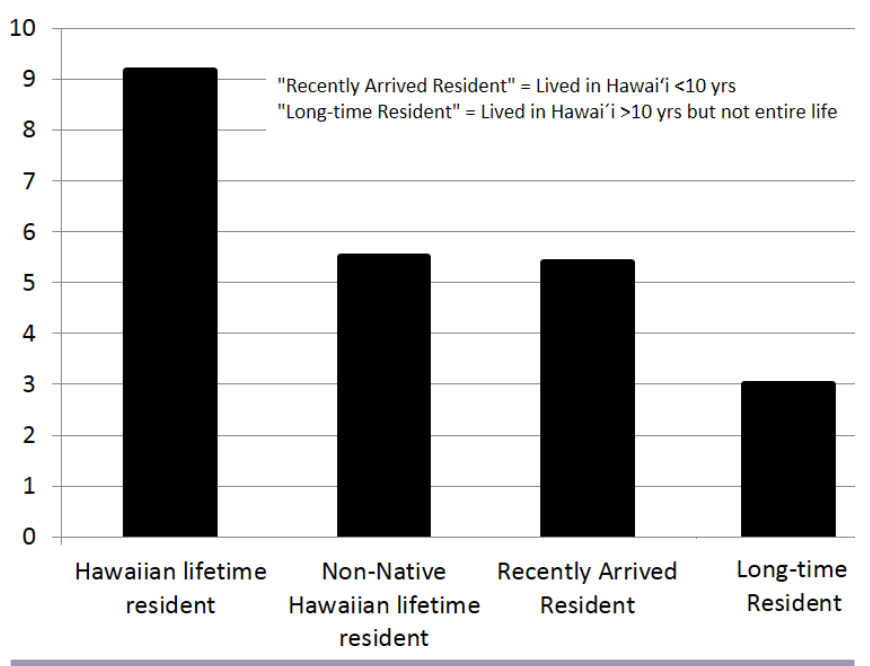


A Hawaiian woman in her fifties described how a combination of heritage and biodiversity underlie her valuation of particular trees:

I don't just value those lama trees [Diospyros sandwicensis] because of their genetic curiosity and particularity, although that's really cool. I value them because I know that my grandmas sat in the shade of them....

As a final example, one Hawaiian woman in her thirties referred to identity in her description of how she was comforted that despite the influx of nonnative plants, natives are "still there." She continued, "That gives me a sense of identity. ... I can breathe because I know that there's something that still exists that is native. Like [sighs], OK. I'm OK. It's still there.

Access

Although no interview questions specifically inquired about notions related to access, 25 of 30 interviewees brought up the issue. Kona's forests are mostly privately owned and access to them is heavily restricted. As one interviewee described it: "South Kona's forests are basically inaccessible. ... Literally, you cannot get into them." Although this comment was an exaggeration, interviewees of all backgrounds discussed limitations to access. In the survey, however, lack of access was less of a concern. The median rating for the statement, "In South Kona in particular, it is easy to access Native Hawaiian Forest when I want to," was a 3 , i.e., moderate, on a scale of 1 to 5 . There were no differences based on ethnicity, residence time, age, or level of education.

Interviewees contemplated how access affects human relationships with the forest. One interviewee said: "So I think the forest is kind of invisible, and ... that fact that there's no access to it, I think makes it invisible." Similarly, a number of interviewees noted how limited access impeded the ability to experience CES:

Increased access would be helpful. ... There'd be more awareness of what's going on, and also I think that the community would value the forest more if they were able to use it more.

Another interviewee noted that, although he advocated increased public access to Kona's forests, "public access means different things to different people." He continued, "That means that I can drive my four-wheel vehicle up there, or I can drive my all-terrain vehicle and alter the forest, right? That's what a lot of people mean by ... public access. Well, I don't want that. I don't even want trails put in because that's harmful."

\section{Ethnic diversity}

Of 30 interviewees, 24 commented on differences between or relationships among ethnicities, particularly between Native and non-Native Hawaiians. One woman, a Native Hawaiian in her seventies, described an interaction with the kinolau of her family's aumakua, the physical manifestation of a guardian ancestor, in a Hawaiian owl, the pueo (Asio flammeus sandwichensis). Experiences like her interaction, she says, encourage a person to "stop, and take a good look at your life, yourself, those around you. ... Are you right with yourself? If not, then you're not being right with the others and all of that. The non-Hawaiians don't look at that; they think it's superstitious or silly or frivolous."

Numerous other respondents of various backgrounds made similar statements about how perspectives of Native Hawaiians and non-Native Hawaiians might differ. A recently arrived white woman in her forties reflected:
I'm sure that there are white people that would respect the forest as much. But I think the Hawaiians definitely have a stronger connection to the forest. ... Perhaps because I'm an outsider, as much as I would want the forest to flourish, I don't have that really special connection to it, but I feel the Hawaiians would.

Another recently arrived white woman in her fifties also expressed the idea of different views of land:

The problem is that Western people come in with their different views of things. ... They see land as private property; whatever they want to do with it, they can. Hawaiians don't see things that way; they see it as they need to take care of their neighbor. You can't just do anything with the land.

A number of interviewees discussed how many of the characteristics associated with Native Hawaiians, white people, or those of other ethnicities were not necessarily related to the koko, that is, the blood. One man in his forties, a lifelong resident of Kona, expressed this perspective:

\begin{abstract}
On paper I am of Japanese ancestry. As far as my beliefs ... being born and raised here, being connected to the land and to the people, I have a lot of beliefs in the traditional Hawaiian ways. Taking care of the land, providing, and treating people well.... I think that people that have those values, no matter ... where they're from ... in spirit, they're Hawaiians.
\end{abstract}

\section{References to colonialism}

Postcolonial issues, i.e., references to Hawai' $i$ in the aftermath of settler, missionary, or U.S. incursion on Hawaiian lands, though not included in the interview guide, were raised and discussed with gravity by 19 of 30 interviewees from a diversity of backgrounds. Native Hawaiians often spoke of these issues using explicit and highly personal references. One Native Hawaiian respondent in his thirties referenced the relationship between postcolonial tension, spirituality, heritage, and identity:

I am indigenous to Hawai' $i$, and you're going to tell me I cannot go and see my spiritual church of my government, of my people, for free? Oh, you guys own the beach now? Oh, it's a national park? I don't give a damn.

A Native Hawaiian woman in her seventies encapsulated concepts addressed by other interviewees:

Much of our land has been so misused: sold, swapped, traded out, for other things that they feel would be beneficial to the overall. And that's always debatable... and we've permitted it. We've allowed it to happen, because we didn't know how to fight in this arena. We never had to fight over land. Land was always available for all to use.... But, with societal changes, now you have to abide by different rules. ... These changes over scores of years have caused many a conflict ... the pain, and the anxiety. ... Anger, frustration, how come, everybody else, old man, and not us? This is our home. How come? 
One Native Hawaiian interviewee commented on postcolonial issues by referencing the 1990 movie Pretty Woman. She recalled the movie's conclusion, when the male lead asks the female lead what she will do now that her "knight in shining armor" has rescued her. She responds that she will "rescue him right back." The interviewee referred to that sentiment to express the current situation in Hawai' $\mathrm{i}$ :

That's ... one of my favorite lines. So, that's the position that the Natives are in now. We keep getting rescued. And, you know, we're being rescued-we got "rescued" by the missionaries, we got "rescued" by the entrepreneurs, now we're being "rescued" by the environmentalists. And it's like, "Yay, we get another chance, to rescue you right back!"

\section{DISCUSSION}

Aspects of the nonmaterial needs and values humans associate with ecosystems, such as nature's positive effects on mental health, seem somewhat universal (Bratman et al. 2012, Russell et al. 2013). Many nonmaterial values, however, are experienced differently by different people. In this study, we found that for people in Kona, spirituality, heritage, and identity were particularly salient categories of what can be called CES, despite how articulation and distribution of these categories vary across backgrounds. We also found that, when discussing ecosystems, respondents reflected repeatedly and deeply on related, nonprompted themes, including ecosystem access, ethnic diversity, and postcolonial tensions.

We aimed to characterize locally based and culturally mediated values for future incorporation into decision making. For research and management, variability in these values is a central concern and challenge; poor understanding of these values and their variability can exacerbate inequities and cripple conservation efforts (Borgerhoff-Mulder and Coppolillo 2005). Our results suggest that understanding CES can help address concerns about the insensitivity of conservation initiatives to human needs and values (Brown 2003), because the combination of qualitative and quantitative social data can improve understanding of complex context-specific issues (van Woerden et al. 2008).

Examples demonstrate the potential influence of CES-related data in decision contexts. Papahānaumokuākea is a cluster of small islands southwest of Hawai'i. Nonmaterial values figured prominently in the decision to designate the area a U.S. National Marine Monument and UNESCO World Heritage Site (UNESCO 2010). In the United Kingdom, qualitative data from a series of focus groups substantially informed the UK National Ecosystem Assessment, a government initiative (Church et al. 2011). CES-related data are also influencing planning decisions in several engagements of the Natural Capital Project, including in Belize, Canada's Vancouver Island, and Baoxing County, China (Ruckelshaus et al. 2013). We see opportunity to more systematically include CES as methods and approaches are refined and communicated to practitioners.

Many peer-reviewed empirical assessments of CES use quantitative data (e.g., Martín-López et al. 2009, Rees et al. 2010, Martín-López et al. 2012, Norton et al. 2012). The research described in this article adds to the CES dialogue by combining more quantitative approaches with narrative descriptions of values that are difficult to encapsulate using traditional quantitative metrics (Natural England 2009, Tengberg et al. 2012, Satterfield et al. 2013) and by opening the possibility for expressing unanticipated values. These two attributes may be particularly critical for incorporating the viewpoints of individuals or groups accustomed to storing and communicating information in nonquantitative formats such as oral histories, myths, or cultural landscapes (Smith 2005, Taylor 2009b, Meskell 2012).

\section{Spirituality, heritage, and identity}

The CES themes we discuss are all deeply complex; we cannot address all nuances here. Even the definition of spirituality is riddled with complications (Speck 2005). Although for many English speakers, spirituality has core meaning related to "an understanding of how life should be lived and an attempt to live that way" (Gottlieb 2012:5), the word's additional trappings vary immensely. Our respondents discussed multiple forms of spirituality, including dark green religion/spiritual ecology (Taylor 2009a, Sponsel 2014), Christianity, and traditional Hawaiian spirituality, which interlinks with Native Hawaiian heritage (Kamakau 1991, Maly 2001, McGregor 2007).

Our results demonstrate that, although some CES vary within a given population (identity and heritage were notable in this regard), others may not; and critically, this variability is not always predictable based on widely held assumptions. Theory and past empirical work suggest, for example, that indigenous peoples' spirituality is often more intricately connected to ecosystems than are other forms of spirituality, particularly traditional Western religions (White 1967, Coates et al. 2006, Nadasdy 2007, Berkes 2008). Recent work has shown, however, that spiritual feelings intertwined with nature are not limited to indigenous people (Gottlieb 2012). The sacredness of nature and nature's processes has been discussed for years (e.g., Birch 1965) and variously termed ecospiritual (Coates et al. 2006), spiritual ecology (Sponsel 2007), and dark green religion (Taylor 2009a). Consistent with the literature, our findings indicate that people of diverse backgrounds feel strong spiritual connections to ecosystems.

Similarly, although some scholarship posits that animistic viewpoints are more commonly found among indigenous than nonindigenous populations (Nadasdy 2007), in our study, people of all backgrounds addressed animism unprompted. Native Hawaiians who discussed animism tended to mention it frequently, but a higher proportion of recent arrivals discussed the topic. Recent religious scholarship has similarly found that people of nonindigenous descent express animistic viewpoints (Harvey 2006, Taylor 2009a, Sponsel 2014).

Heritage, i.e., legacies from the past as they relate to Kona's ecosystems, was the second leading theme in our study. Heritage is a complex contemporary political topic involving multiple relations between self and group, group and dominant other, and group and government, with all of these relations embedded within a system of "changing perspectives and identities" (Cheape et al. 2009:105). Both our survey and interview data suggest that cultural heritage is strongly linked to forest for many residents of Hawai' $i$, particularly for Native Hawaiians. This result is consistent with the renewed respect for and celebration of Native Hawaiian heritage and culture in present-day Hawaiian society (Blackford 2004, McGregor 2007). 
Understanding the relationships between Hawaiian ecosystems, Native Hawaiians today, and their heritage may be especially important for decision making. Material, aesthetic, and scientific discourses have dominated in the management of heritage (Baird 2012). One frontier of heritage studies centers on attention to intangible heritage, which may aid "understandings around natural and cultural patrimony" (Meskell 2012:35).

Identities are complex: all-encompassing (Wheaton 2011), dynamic (Kahn 2003), and multiple (Falk 2006, Kelty 2011). Our results touch on each of these characteristics. The relationship between identity and place is addressed in Western literature from two primary directions: nature as an element of overall identity formation (Proshansky et al. 1983, Twigger-Ross and Uzzell 1996) and identity as a component of place attachment, that is, a bond based on thoughts and emotions (Stedman 2002). Environmental identity studies refer to "nature" at varying scales, from a relatively abstract and generalized concept of nature (Schultz 2001, Clayton and Opotow 2003) to specific geographic locations (Williams and Vaske 2003).

Our work focused on the relationship between a person's overall identity and a particular place, a combination uncommon in the literature. We found that lifelong residents of Kona had particularly strong identity-related connections to Kona's ecosystems. Respondents' discussions of identity, however, were not directly associated with duration of residence, but rather addressed nuanced ways in which Kona's ecosystems interact with identity: as deeply integral to identity, as integral to identity and mediated by activity, and as relatively unconnected to identity. This finding has important, if difficult to operationalize, implications for socially conscious land management.

The values discussed herein interlink in multiple ways. In their relationships to ecosystems, identity and cultural heritage are often connected (Cheape et al. 2009, Baird 2012), as are heritage and spirituality (West and Brockington 2006) and spirituality and identity (Maly 2001). All three values can also be interrelated, as we and others have found (Berkes 2008). Our findings also provide evidence of the interrelatedness of nonmaterial and material ES (Chan et al. 2012a): Respondents repeatedly mentioned the spiritual power of nature's life-sustaining characteristics (Berkes 2008). This point has obvious links to ecosystem services: Our respondents essentially described the sacredness of material ecosystem services. This finding relates to research demonstrating the centrality of the supernatural in some societies' customary management regimes (e.g., Sasaoka and Laumonier 2012).

\section{Unanticipated themes}

We are aware and wary of the implications of categorizing myriad values within a particular framework, i.e., ecosystem services (Foucault 1973, Brosius 2010). Thus, we are particularly attentive to emerging concerns. In this analysis, we focus on access, ethnic diversity, and postcolonial stressors.

The prevalence of access-related discussions suggests an emergent area of concern and potential emphasis for future CES-related research: how availability of and access to ecosystems affect the potential for nonmaterial benefits from those systems. Land tenure and associated use rights have affected people's relationships with land for millennia (Scott 1998); exclusion from ecosystems can dramatically erode ecosystem-associated material
(Hall et al. 2011) and nonmaterial (Schein 2009) values. Largely because of these effects, access has been considered central to environmental management (Lockie 2013). In present-day Hawai ' $\mathrm{i}$, issues of tenure and exclusion are a major concern (McGregor 1996, Herman 1999), and our results indicate that many people in Kona consider current access to the forest restricted. Some respondents referred to access as a right: a legal or moral claim. Others referred to it as a benefit or opportunity that is desirable but not fundamental. This diversity is consistent with discussions in the natural-resources literature around the critical distinction, in considerations of access, between rights and benefits (Ribot and Peluso 2003). Regardless of how they referred to it, access was clearly a concern for most respondents. Future CES studies may consider access as a mediator of CES.

A second emerging theme, relationships between people of different ethnicities, relates to the variability of CES within a given geographic population. In Kona, the dimensions most often associated with differences in the people-ecosystem relationship were ethnicity and length of residence. This point is connected to postcolonial issues in that the group with historic power have been newcomers and are ethnically different from the precolonial population.

Ethnicity tends to be a prevalent concern in Hawai' $i$ in both private and public life (Trask 1991); combined with interviewees' unprompted discussions of ethnic diversity, this consideration led us to explore variations in CES along ethnic lines. Discussions of issues such as ethnic relations are complicated by numerous factors, among them that differences are perceived, rather than representing some absolute truth, and tend toward generalization (Operario and Fiske 2002). With respect to such complex, socially mediated issues, however, these perceived, context-laden views are probably a necessary format for representing these phenomena, and from some epistemological perspectives, the only accurate format (Brosius 2010).

In addition to the contextual factors of access and ethnic diversity, postcolonial concerns emerged as relevant to the analysis of nonmaterial values (Berkes 2004). In places where colonization and subsequent decolonization play a central role in sociocultural history, any exploration of the values associated with land is likely to raise issues of colonial history, justice, and ownership (West 2006). Hawai'i's vibrant, highly functioning society was taken over by colonizing powers in recent historical memory (Lili‘uokalani 1991, McCubbin and Marsella 2009); that takeover was associated with the control and commercialization of land and natural resources. Thus, it is not surprising that postcolonial discourse and impact emerged in this study as key elements of the human-ecosystem relationship. Postcolonial studies clearly establish that settings with colonial histories often have complex and painful power dynamics (Gilbert and Tompkins 1996, Saïd 2002) and that land can be a focus for these painful pasts (Meskell 2012).

Respondents addressed postcolonial concerns frequently and with great intensity, although we did not prompt for discussion of these sensitive issues. One respondent's reference to the film Pretty Woman and its idea of "rescuing" offers insight into how postcolonial issues continually manifest in Kona and supports the notion that a fictional narrative may facilitate discussion of sensitive issues (Gould et al. 2010). The comment that Native 
Hawaiians will "rescue you right back" suggests that the Hawaiian people/culture have much to teach the rest of the world. A primary sentiment of this quote, that of the arrogance of self-proclaimed "saviors" or "helpers" from outside who have the goal of benefiting a place and its people (Trask and Hayslip 1999, Cole 2012), infused many interview and survey comments. Given the typical composition of research and conservation teams, special attention to this point may be in order, in the form of openness to critique and discussion, in-depth local participation, and consideration of diverse ways of knowing (Brosius 2010).

\section{Limitations and future directions}

Attempts to elicit CES in explicit terms make three assumptions: that these values exist; that they can be suitably articulated; and that people will express them honestly to researchers (Schultz and Tabanico 2007), especially outsiders. Although some scholars recommend implicit tests of these attitudes (Schultz and Tabanico 2007), such tests would not have served our purpose of understanding a diversity of values in terms relevant to respondents. They may, however, be appropriate at later stages of CES research and for analysis of particular values.

Given that this study used explicit questioning, our survey and interview responses were clearly sensitive to our list of predefined values (Foucault 1973, Brown 2005). We piloted numerous measures of complex, nuanced values using explicit survey items; addressing such abstract values in this format raises questions of face validity (Brown 2005). Our heritage results support the face validity of our survey items measuring those constructs. Our spirituality and identity results suggest that this survey construct requires further refinement. Our spirituality results suggest that this survey construct requires further refinement.

Our findings suggest that certain CES may lend themselves more readily to analysis by quantitative metrics, whereas others may be better characterized by discourse and discussion. Future work can refine mixed-methods approaches to elicit and understand particular values such as spirituality. With careful design and piloting, quantitative measures may be appropriate, allowing both positivistic and more interpretive or constructivist epistemologies to guide research (Sponsel 2007).

Our survey had two logistical limitations. First, because this study was exploratory, we addressed a large number of constructs using a single survey item rather than a multi-item construct (Babbie 2009). Second, we used a convenience sample, which precluded drawing conclusions about the larger population (Babbie 2009). We maintain, however, that this was the most socially appropriate and effective way to reach people in our study setting.

Data collection, analysis, and interpretation were affected in diverse and partly unknown ways by the varying levels of "insideness" of the researchers. That outsiders' understanding of culture and setting differs from insiders' perspectives has benefits and drawbacks (Smith 2005, Theroux 2012). Researchers were thus careful to consider reflexivity in their interactions (Bourdieu and Wacquant 1992, Alvesson and Sköldberg 2009).

Despite limitations, our findings offer insight into advances in ES theory and practice. They provide an example of CES organized into more specific categories than those proposed by the Common International Classification of Ecosystem Services (HainesYoung and Potschin 2013). Thus, our findings can inform continued efforts to refine and standardize the treatment of social and cultural dimensions of ES, including discussions of how the ES framework can account for the interdependent, i.e., not oneway producer-to-consumer, character of ecosystem-human relationships (von Heland and Folke 2014).

\section{CONCLUSION}

In many ways, land management requires balancing contrasting and competing interests (Brown 2005). Methods such as those tested in this study can refine distinctions among multiple constituencies and individuals. Consequently, they can provide vital input for deliberative decision making (Fishkin 2009, Gregory et al. 2012) and help to address the social equity, i.e., distributional, impacts of ES decisions (Wilson and Howarth 2002). One critical concern with any deliberative or participatory process relates to who is involved and influential, because certain segments of society are less likely to participate (Burch 1976). CES analyses, which seek to understand a diversity of perspectives, can provide quantitative and qualitative input for these decision-making contexts, while also helping guide who should be present to ensure representation of certain viewpoints. In this way, research and methods such as those described here offer a process for making visible a diversity of values. In many decision-making contexts, more explicit values may allow for more informed decisions, and possibly, more just ones.

Responses to this article can be read online at: http://www.ecologyandsociety.org/issues/responses. $\mathrm{php} / 6893$

\section{Acknowledgments:}

We are deeply grateful to our study participants, who graciously shared their time, energy, and stories. Kanani Enos and Shane Akoni Nelsen were instrumental in sharing results with the study community through performance (see http://www. researchspeaks. org). We thank the U.S. National Center for Ecological Analysis and Synthesis and our fellow members of the Cultural Ecosystem Services Working Group: P. Balvanera, X. Basurto, A. Bostrom, $K$. Chan, A. Guerry, B. Halpern, S. Klain, J. Levine, B. Norton, and $J$. Tam. For research support, we thank the Center for Conservation Biology, the Stanford School of Earth Sciences, the Winslow Foundation, and the Heinz Foundation.

\section{LITERATURE CITED}

Alvesson, M., and K. Sköldberg. 2009. Reflexive methodology: new vistas for qualitative research. Sage, Thousand Oaks, California, USA.

Babbie, E. R. 2009. The practice of social research. Wadsworth, Independence, Kentucky, USA.

Baird, M. F. 2012. 'The breath of the mountain is my heart': indigenous cultural landscapes and the politics of heritage. International Journal of Heritage Studies 19(4):327-340.

Berkes, F. 2004. Rethinking community-based conservation. Conservation Biology 18:621-630. http://dx.doi.org/10.1111/ j.1523-1739.2004.00077.x 
Berkes, F. 2008. Sacredecology. Taylor \& Francis, New York, New York, USA.

Birch, C. 1965. Nature and God. Westminster, Louisville, Kentucky, USA.

Blackford, M. G. 2004. Environmental justice, native rights, tourism, and opposition to military control: the case of Kaho'olawe. Journal of American History 91:544-571. http://dx. doi.org/10.2307/3660711

Borgerhoff-Mulder, M., and P. Coppolillo. 2005. Conservation: linking ecology, economics and culture. Princeton University Press, Princeton, New Jersey, USA.

Bourdieu, P., and L. J. Wacquant. 1992. An invitation to reflexive sociology. University of Chicago Press, Chicago, Illinois, USA.

Bratman, G. N., J. P. Hamilton, and G. C. Daily. 2012. The impacts of nature experience on human cognitive function and mental health. Annals of the New York Academy of Sciences 1249:118-136. http://dx.doi.org/10.1111/j.1749-6632.2011.06400. $\underline{\mathrm{X}}$

Brosius, J. P. 2010. Conservation trade-offs and the politics of knowledge. Page 311 in N. Leader-Williams, W. M. Adams, and R. J. Sith, editors. Trade-offs in conservation: deciding what to save. Wiley-Blackwell, Hoboken, New Jersey. http://dx.doi. org/10.1002/9781444324907.ch17

Brown, G. 2005. Mapping spatial attributes in survey research for natural resource management: methods and applications. Society \& Natural Resources 18:17-39. http://dx.doi.org/10.1080/089419$\underline{20590881853}$

Brown, K. 2003. Three challenges for a real people-centred conservation. Global Ecology and Biogeography 12:89-92. http:// dx.doi.org/10.1046/j.1466-822X.2003.00327.x

Burch, W. R. 1976. Who participates? A sociological interpretation of natural resource decisions. Natural Resources Journal 16:41.

Chan, K., J. Goldstein, T. Satterfield, N. Hannahs, K. Kikiloi, R. Naidoo, N. Vadeboncoeur, and U. Woodside. 2011. Cultural services and non-use values. Pages 206-228 in P. Kareiva, H. Tallis, T. H. Ricketts, G. C. Daily, and S. Polasky, editors. Natural capital: theory \& practice of mapping ecosystem services. Oxford University Press, Oxford, UK. http://dx.doi.org/10.1093/acprof: oso/9780199588992.003.0012

Chan, K., T. Satterfield, and J. Goldstein. 2012a. Rethinking ecosystem services to better address and navigate cultural values. Ecological Economics 74:8-18. http://dx.doi.org/10.1016/j. ecolecon.2011.11.011

Chan, K. M. A., A. D. Guerry, P. Balvanera, S. Klain, T. Satterfield, X. Basurto, A. Bostrom, R. Chuenpagdee, R. Gould, B. S. Halpern, N. Hannahs, J. Levine, B. Norton, M. Ruckelshaus, R. Russell, J. Tam, and U. Woodside. 2012b. Where are cultural and social in ecosystem services? A framework for constructive engagement. BioScience 62:744-756. http://dx.doi.org/10.1525/ bio.2012.62.8.7

Cheape, H., M. C. Garden, and F. McLean. 2009. Heritage and the environment [Introduction to special issue]. International
Journal of Heritage Studies 15:101-272. http://dx.doi. org/10.1080/13527250902890597

Church, A., J. Burgess, and N. Ravenscroft. 2011. Cultural services. Pages 633-692 in U.K. National Ecosystem Assessment. United Nations Environment Programme-World Conservation Monitoring Centre, Cambridge, UK.

Clayton, S. D., and S. Opotow. 2003. Identity and the natural environment: the psychological significance of nature. MIT Press, Cambridge, Massachussetts, USA.

Coates, J., M. Gray, and T. Hetherington. 2006. An 'ecospiritual' perspective: finally, a place for indigenous approaches. British Journal of Social Work 36:381-399. http://dx.doi.org/10.1093/ bjsw/bcl005

Cole, T. 2012. The white-savior industrial complex. The Atlantic, 21 March. [online] URL: http://servicelearning.boisestate.edu/ students/files/2014/01/The-White-Savior-Industrial-Complex-TejuCole-The-Atlantic.pdf

Creswell, J., A. Klassen, V. P. Clark, and K. Smith. 2011. Best practices for mixed methods research in the health sciences. Office of Behavioral and Social Sciences Research, National Institutes of Health, Bethesda, Maryland, USA. http://dx.doi.org/10.1037/ e566732013-001

Creswell, J. W., and V. L. P. Clark. 2007. Designing and conducting mixed methods research. Sage, Thousand Oaks, California, USA.

Daniel, T. C., A. Muhar, A. Arnberger, O. Aznar, J. W. Boyd, K. Chan, R. Costanza, T. Elmqvist, C. G. Flint, P. H. Gobster, A. Grêt-Regameyj, R. Lavek, S. Muharl, M. Penkerm, R. G. Riben, T. Schauppenlehnerb, T. Sikoro, I. Soloviyp, M. Spierenburgq, K. Taczanowskab, J. Tame, and A. von der Dunkj. 2012. Contributions of cultural services to the ecosystem services agenda. Proceedings of the National Academy of Sciences of the United States of America 109(23):8812-8819. http://dx.doi. org/10.1073/pnas.1114773109

Falk, J. H. 2006. An identity-centered approach to understanding museum learning. Curator: The Museum Journal 49:151-166. http://dx.doi.org/10.1111/j.2151-6952.2006.tb00209.x

Fishkin, J. 2009. When the people speak: deliberative democracy and public consultation. Oxford University Press, Oxford, UK.

Foucault, M. 1973. The order of things: an archaeology of the social sciences. Vintage, New York, New York, USA.

Gilbert, H., and J. Tompkins. 1996. Post-colonial drama: theory, practice, politics. Routledge, New York, New York, USA. http:// dx.doi.org/10.4324/9780203421062

Gilbert, N. 2008. Researching social life. Sage, Thousand Oaks, California, USA.

Gottlieb, R. S. 2012. Spirituality: what it is and why it matters. Oxford University Press, New York, New York, USA. http://dx. doi.org/10.1093/acprof:oso/9780199738748.001.0001

Gould, R. K., N. M. Ardoin, and J. K. Hashimoto. 2010. 'Mâlama the 'âina, Mâlama the people on the 'âina': the reaction to avatar in Hawai'i. Journal for the Study of Religion, Nature \& Culture 4 (4):425-456. 
Gould, R. K., S. Klain, N. M. Ardoin, U. Woodside, N. Hannahs, T. Satterfield, K. M. A. Chan, and G. C. Daily. 2014. A protocol for eliciting nonmaterial values using a cultural ecosystem services frame. Conservation Biology, in press.

Gregory, R., L. Failing, M. Harstone, G. Long, T. McDaniels, and D. Ohlson. 2012. Structured decision making: a practical guide to environmental management choices. Wiley-Blackwell, Hoboken, New Jersey, USA. http://dx.doi.org/10.1002/97814443398557

Haines-Young, R., and M. Potschin. 2013. Common International Classification of Ecosystem Services (CICES): consultation on version 4. European Environment Agency, Nottingham, UK.

Hall, D., P. Hirsch, and T. M. Li. 2011. Powers of exclusion: land dilemmas in Southeast Asia. University of Hawaii Press, Honolulu, Hawai'i, USA.

Harvey, G. 2006. Animism: respecting the living world. Columbia University Press, New York, New York, USA.

Herman, R. D. K. 1999. The aloha state: place names and the anti-conquest of Hawai'i. Annals of the Association of American Geographers 89:76-102. http://dx.doi.org/10.1111/0004-5608.00131

IBM. 2012. IBM SPSS statistics for Windows. Version 21. IBM, Armonk, New York, USA.

Kahn, P. H. J. 2003. The development of environmental moral identity. Pages 113-134 in S. Clayton and S. Opotow, editors. Identity and the natural environment. MIT Press, Cambridge, Massachussetts, USA.

Kamakau, S. M. 1991. The people of old. Bishop Museum Press, Honolulu, Hawai'i, USA.

Kellert, S. R., and T. Farnham. 2002. The good in nature and humanity: connecting science, religion, and spirituality with the natural world. Island Press, Washington, D.C., USA.

Kelty, R. 2011. Human dimensions of a fishery at a crossroads: resource valuation, identity, and way of life in a seasonal fishing community. Society and Natural Resources 24:334-348. http://dx. doi.org/10.1080/08941920903476814

Kittinger, J. N., E. M. Finkbeiner, E. W. Glazier, and L. B. Crowder. 2012. Human dimensions of coral reef social-ecological systems. Ecology and Society 17(4): 17. http://dx.doi.org/10.5751/ ES-05115-170417

Klain, S. C., and K. M. A. Chan. 2012. Navigating coastal values: participatory mapping of ecosystem services for spatial planning. Ecological Economics 82:82: 104-113. http://dx.doi.org/10.1016/ j.ecolecon.2012.07.008

Lili'uokalani. 1991. Hawai'i’s story by Hawai' i’s queen [Originally published 1898]. Mutual, Honolulu, Hawai'i, USA.

Lockie, S. 2013. Market instruments, ecosystem services, and property rights: assumptions and conditions for sustained social and ecological benefits. Land Use Policy 31:90-98. http://dx.doi. org/10.1016/j.landusepol.2011.08.010

Maly, K. 2001.Mālama pono ika 'āina: an overview of the Hawaiian cultural landscape. Kumu Pono Associates LLC, Hilo, Hawai'i, USA.
Mann, H. B., and D. R. Whitney. 1947. On a test of whether one of 2 random variables is stochastically larger than the other. Annals of Mathematical Statistics 18:50-60. http://dx.doi. org/10.1214/aoms/1177730491

Martín-López, B., E. Gómez-Baggethun, P. L. Lomas, and C. Montes. 2009. Effects of spatial and temporal scales on cultural services valuation. Journal of Environmental Management 90:1050-1059. http://dx.doi.org/10.1016/j.jenvman.2008.03.013

Martín-López, B., I. Iniesta-Arandia, M. García-Llorente, I. Palomo, I. Casado-Arzuaga, D. G. D. Amo, E. GómezBaggethun, E. Oteros-Rozas, I. Palacios-Agundez, B. Willaarts, J. A. González, F. Santos-Martín, M. Onaindia, C. LópezSantiago, and C. Montes. 2012. Uncovering ecosystem service bundles through social preferences. PLOS ONE 7:e38970. http:// dx.doi.org/10.1371/journal.pone.0038970

Maxwell, J. A. 2005. Qualitative research design: an interactive approach. Sage, Thousand Oaks, California, USA.

McCauley, D. J. 2006. Selling out on nature. Nature 443:27-28. http://dx.doi.org/10.1038/443027a

McCubbin, L. D., and A. Marsella. 2009. Native Hawaiians and psychology: the cultural and historical context of indigenous ways of knowing. Cultural Diversity \& Ethnic Minority Psychology 15:374-387.

McGregor, D. 2007. Nâ kua'âina: living Hawaiian culture. University of Hawai'i Press, Honolulu, Hawai'i, USA.

McGregor, D. P. 1996. An introduction to the Hoa'ina and their rights. Hawaiian Journal of History 30:1-27.

Meskell, L. 2012. The nature of heritage: the new South Africa. John Wiley \& Sons, Chichester, West Sussex, UK.

Millennium Ecosystem Assessment. 2005. A framework for assessment. Island Press, Washington, D.C., USA.

Nadasdy, P. 2007. The gift in the animal: the ontology of hunting and human-animal sociality. American Ethnologist 34:25-43. http://dx.doi.org/10.1525/ae.2007.34.1.25

Nakagawa, S. 2004. A farewell to Bonferroni: the problems of low statistical power and publication bias. Behavioral Ecology 15:1044-1045. http://dx.doi.org/10.1093/beheco/arh107

Natural England. 2009. Experiencing landscapes: capturing the cultural services and experiential qualities of landscape. Commissioned Report NECR024. Natural England, Sheffield, UK.

Norton, L., H. Inwood, A. Crowe, and A. Baker. 2012. Trialling a method to quantify the 'cultural services' of the English landscape using Countryside Survey data. Land Use Policy 29:449-455. http://dx.doi.org/10.1016/j.landusepol.2011.09.002

Operario, D., and S. T. Fiske. 2002. Stereotypes: content, structures, processes, and context. Pages 22-44 in R. Brown and S. Gaertner, editors. Blackwell handbook of social psychology: intergroup processes. Blackwell, Hoboken, New Jersey, USA. http://dx.doi.org/10.1002/9780470693421.ch2 
Patton, M. Q. 2002. Qualitative research \& evaluation methods. Third edition. Sage, Thousand Oaks, California, USA.

Pickett, S., W. R. Burch, Jr., and J. M. Grove. 1999. Interdisciplinary research: maintaining the constructive impulse in a culture of criticism. Ecosystems 2:302-307. http://dx.doi. org/10.1007/s100219900081

Proshansky, H. M., A. K. Fabian, and R. Kaminoff. 1983. Placeidentity: physical world socialization of the self. Journal of Environmental Psychology 3:57-83. http://dx.doi.org/10.1016/ $\underline{\mathrm{S} 0272-4944(83) 80021-8}$

Rees, S. E., L. D. Rodwell, M. J. Attrill, M. C. Austen, and S. C. Mangi. 2010. The value of marine biodiversity to the leisure and recreation industry and its application to marine spatial planning. Marine Policy 34:868-875. http://dx.doi.org/10.1016/j.marpol.2010.01.009

Ribot, J. C., and N. L. Peluso. 2003. A theory of access. Rural Sociology 68:153-181. http://dx.doi.org/10.1111/j.1549-0831.2003. $\underline{\mathrm{tb} 00133 . \mathrm{x}}$

Ruckelshaus, M., E. McKenzie, H. Tallis, A. Guerry, G. Daily, P. Kareiva, S. Polasky, T. Ricketts, N. Bhagabati, S. A. Wood, and J. Bernhardt. 2013 Notes from the field: lessons learned from using ecosystem service approaches to inform real-world decisions. Ecological Economics 23, in press.

Russell, R., A. D. Guerry, P. Balvanera, R. K. Gould, X. Basurto, K. M. A. Chan, S. Klain, J. Levine, and J. Tam. 2013. Humans and nature: how knowing and experiencing nature affect wellbeing. Annual Review of Environment and Resources 38:473-502. http://dx.doi.org/10.1146/annurev-environ-012312-110838

Saï, E. W. 2002. Power, politics, and culture. Vintage, New York, New York, USA.

Samuels, M. L., and J. A. Witmer. 2003. Statistics for the life sciences. Third edition. Pearson Education, Upper Saddle River, New Jersey, USA.

Sasaoka, M., and Y. Laumonier. 2012. Suitability of local resource management practices based on supernatural enforcement mechanisms in the local social-cultural context. Ecology and Society 17(4): 6. http://dx.doi.org/10.5751/ ES-05124-170406

Satterfield, T., R. Gregory, S. Klain, M. Roberts, and K. M. Chan. 2013. Culture, intangibles and metrics in environmental management. Journal of Environmental Management 117:103-114. http://dx.doi.org/10.1016/j.jenvman.2012.11.033

Satz, D., R. K. Gould, K. M. A. Chan, A. Guerry, B. Norton, T. Satterfield, B. S. Halpern, J. Levine, U. Woodside, N. Hannahs, X. Basurto, and S. Klain. 2013. The challenges of incorporating cultural ecosystem services into environmental decision-making. Ambio 42(6):675-684. http://dx.doi.org/10.1007/s13280-013-0386-6

Schaich, H., C. Bieling, and T. Plieninger. 2010. Linking ecosystem services with cultural landscape research. GaiaEcological Perspectives for Science and Society 19:269-277.

Schein, R. H. 2009. Belonging through land/scape. Environment and Planning A 41(4):811-826. http://dx.doi.org/10.1068/a41125

Schultz, P., and J. Tabanico. 2007. Self, identity, and the natural environment: exploring implicit connections with nature. Journal of Applied Social Psychology 37:1219-1247. http://dx.doi. org/10.1111/j.1559-1816.2007.00210.x

Schultz, P. W. 2001. The structure of environmental concern: concern for self, other people, and the biosphere. Journal of Environmental Psychology 21:327-339. http://dx.doi.org/10.1006/ jevp.2001.0227

Scott, J. C. 1998. Seeing like a state: how certain schemes to improve the human condition have failed. Yale University Press, New Haven, Connecticut, USA.

Shirk, J. L., H. L. Ballard, C. C. Wilderman, T. Phillips, A. Wiggins, R. Jordan, E. McCallie, M. Minarchek, B. V. Lewenstein, and M. E. Krasny. 2012. Public participation in scientific research: a framework for deliberate design. Ecology and Society 17(2): 29. http://dx.doi.org/10.5751/ES-04705-170229

Smith, L. T. 2005. Decolonizing methodologies: research and indigenous peoples. Zed Books, London, UK.

Speck, B. W. 2005. What is spirituality? New Directions for Teaching and Learning 104:3-13. http://dx.doi.org/10.1002/t1.207

Sponsel, L. E. 2007. Spiritual ecology: one anthropologist's reflections. Journal for the Study of Religion, Nature and Culture 1:340-350. http://dx.doi.org/10.1558/jsrnc.vli3.340

Sponsel, L. E. 2014. Spiritual ecology. Pages 1718-1723 in D. A. Leeming, editor. Encyclopedia of psychology and religion. Second edition. Springer, New York, New York, USA. http://dx.doi. org/10.1007/978-1-4614-6086-2 9295

Stedman, R. C. 2002. Toward a social psychology of place predicting behavior from place-based cognitions, attitude, and identity. Environment and Behavior 34:561-581. http://dx.doi. org/10.1177/0013916502034005001

Taylor, B. 2009a. Dark green religion: nature spirituality and the planetary future. University of California Press, Berkeley, California, USA.

Taylor, D. F. 2009b. Some new applications in the theory and practice of cybercartography: mapping with indigenous people in Canada's North. Proceedings of the 24th International Cartographic Conference. International Cartographic Association, Santiago, Chile.

Tengberg, A., S. Fredholm, I. Eliasson, I. Knez, K. Saltzman, and O. Wetterberg. 2012. Cultural ecosystem services provided by landscapes: assessment of heritage values and identity. Ecosystem Services 2:14-26. http://dx.doi.org/10.1016/j.ecoser.2012.07.006

Theroux, P. 2012. Paul Theroux's quest to define Hawaii. Smithsonian Magazine May:61-64, 98-100, 102.

Trask, H.-K. 1991. Coalition-building between natives and nonnatives. Stanford Law Review 43:1197-1213. http://dx.doi. org/10.2307/1229037

Trask, H. K., and L. L. Hayslip. 1999. From a native daughter. Revised edition. University of Hawai'i Press, Honolulu, Hawai'i, USA.

Tucker, M. E., and J. A. Grim. 2001. Introduction: the emerging alliance of world religions and ecology. Daedalus 130:1-22. 
Twigger-Ross, C. L., and D. L. Uzzell. 1996. Place and identity processes. Journal of Environmental Psychology 16:205-220. http://dx.doi.org/10.1006/jevp.1996.0017

UNESCO. 2010. Report of the decisions adopted by the World Heritage Committee. UNESCO, Brasilia, Brazil.

U.S. Census Bureau. 2010. Census 2000 summary file 1. U.S. Census Bureau, Washington, D.C., USA.

U.S. Environmental Protection Agency (EPA) Science Advisory Board. 2009. Valuing the protection of ecological systems and services: a report of the Science Advisory Board. U.S. Environmental Protection Agency, Washington, D.C., USA.

van Woerden, J., C. Wieler, E. Gutierrez-Espeleta, R. Grosshans, A. Abdelrehim, and P. C. L. Rajbhandari. 2008. IEA training manual: training module 4, monitoring, data, and indicators. United Nations Environment Program, Nairobi, Kenya.

von Heland, J., and C. Folke. 2014. A social contract with the ancestors - culture and ecosystem services in southern Madagascar. Global Environmental Change 24:251-264. http://dx. doi.org/10.1016/j.gloenvcha.2013.11.003

West, P. 2006. Conservation is our government now: the politics of ecology in Papua New Guinea. Duke University Press, Durham, North Carolina, USA. http://dx.doi.org/10.1215/9780822388067

West, P., and D. Brockington. 2006. An anthropological perspective on some unexpected consequences of protected areas. Conservation Biology 20:609-616. http://dx.doi.org/10.1111/ j.1523-1739.2006.00432.x

White, L. 1967. The historical roots of our ecologic crisis. Science 155:1203-1207. http://dx.doi.org/10.1126/science.155.3767.1203

Williams, D. R., and J. J. Vaske. 2003. The measurement of place attachment: validity and generalizability of a psychometric approach. Forest Science 49:830-840.

Wilson, M. A., and R. B. Howarth. 2002. Discourse-based valuation of ecosystem services: establishing fair outcomes through group deliberation. Ecological Economics 41:431-443. http://dx.doi.org/10.1016/S0921-8009(02)00092-7 


\section{Appendix 1. Interview Protocol}

We provide the interview protocol used for semi-structured interviews in Kona.

A similar protocol was implemented in British Columbia; see Gould et al. (2014, A protocol for eliciting nonmaterial values using a cultural ecosystem services frame, Conservation Biology) for reflections on the protocol based on the experience in both sites.

\section{Contributions of Ecosystems to Local Communities}

Before interview:

- Set up map, camera, and tokens

- Make sure recorder is functioning

The interview starts with:

- Introduction of interviewer

- Consent form and confidentially agreement, which includes project description

- Reminder: that this is an exploration and there are no right or wrong answers

- Thanking participant in advance

Start the digital recording device.

\section{Section 1- Start with background questions.}

What is your name? Where were you born?

How long have you lived in Hawai' $i$ ? How about on the Big Island? Here in Kona?

Are you currently working, between jobs, or a student?

What is your occupation?

Do you mind telling me how old you are?

Prompt: If you don't want to share your age, just a ballpark would be fine!

Do you have children? If so, what are their ages? Do you have mo'opuna (grandchildren)?

What ethnic groups do you consider yourself part of?

If you had to choose, which ethnic group would you say you most identify with? 


\section{Would you be willing to share one experience OR a few specific cultural activity experiences, which are tied to the Kahalu'u or Honaunau areas?}

I'd love to get a sense of how often you participate in those activities. So, how often have you participated in the activities you mentioned in the past 6 months?

\section{Section 2-}

Activities in the forest and how you think about the forest.

[Put out map and explain the colors and ahupua'a boundaries]

What activities do you do related to the forests on this map? Using this map, can you show me where you do those activities?

[Mark with black marker]

Just a note: I may say aloud the places you point to as you tell me what you do in certain places. This is so that we have a recording that includes the "pointing" you're doing.

[If appropriate]: How did you come to have your position at X organization? [Doesn't need to be a job; could be an informal relationship]

Can you tell me if and/or why your involvement in [your forest-related business or organization] is important to you?

Has your interest or involvement in issues/business related to land up mauka changed over time? If so, how?

Do you think of the health of the forests up mauka and your own well being as connected in any way?

If so, can you describe that link? How does it work, how do you know it exists, or how strong is that link? 


\section{Section 3- "Health" of Forest}

What does the phrase or idea of "a healthy forest ecosystem" mean to you? What things first come to mind when you hear that phrase?

When you think of a "healthy forest ecosystem," are there parts of that system that come to mind in particular? (What are those parts, and how do you know if a given part is healthy or not?)

Prompt: Are there certain things that indicate a healthy or unhealthy system?

Now, what about a "healthy ahupua'a" - that is, not JUST the forest ecosystem, but also the entire ahupua'a. What do you think of when you think of a healthy ahupua'a?

Ok, let's think about the same question but in reference to healthy human communities instead of forest ones.

What does the term a "healthy human community" mean to you?

What tells you or indicate to you that a community is healthy?

- Feel free to think about 'health' in the broadest sense of the word (i.e. physical, emotional, spiritual, cultural) including any type or dimension of health you want to consider.

So you said earlier that you (DO or DO NOT) see your own well-being as connected to the forests' health.

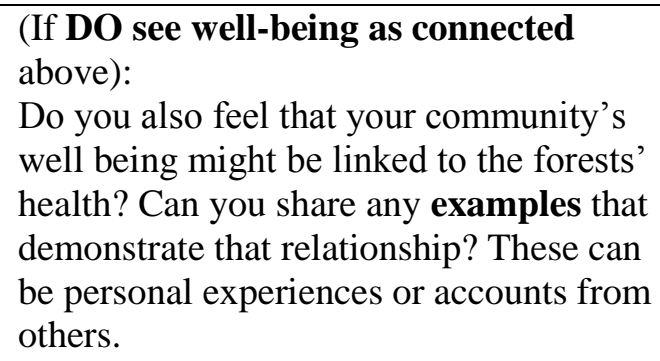

Thanks. Let's return to talking about the forests up mauka.

Can you describe any changes in the health of forests up mauka that you have noticed or heard about over time?

[If respondent only notes changes for the worse, ask them if there are changes for the better, and vice versa]
(If DO NOT see well-being connected above):

Would that answer be any different for your community? That is, do you think that your community's well being might be linked to the forests' health? 


\section{Section 4- Management Opinions/Ideas for Improvement}

Do you think that the management of the forests up mauka needs to be improved?

Are there specific things you think could be done to (better) manage the forests' ecological health? What are they and why do they matter? Feel free to recommend or think out loud about anything that's important.

-- Start recording ideas for improved forest management on notecards -

What about any other factors that might improve the way the forest is managed?

[If respondent hasn't mentioned people]: For instance, we could change the way we manage what people or groups of society can do in the forest. Is there anything you would recommend along these 'people' or human lines?

What about our economy as it relates to the forest -- are there things we should change or manage differently there?

Prompts: What about collection of plants, such as maile? Tourism? Hunting?

Ok, you've mentioned several issues that ought to be addressed to improve forest management. I've written them on these cards. Can you rank these management issues in importance?

[If not responding or not willing to rank]:

Or elaborate on which you feel is most important?

\section{Section 5- Spatial Questions}

Now, a disclaimer:

This series of questions is being asked in a number of places, and we're trying to standardize. So the FIRST question using this map may seem a bit strange. Just play along, if you will ... and the following map questions will hopefully make more sense, although they still might feel strange. Again, this is exploratory.

Gesture towards the laminated map. Get out the green, purple and red fine tipped marker and the colored discs (100 green, 100 purple and 100 red discs), which will be allocated to shapes drawn by interviewees.

Using the green marker, can you draw shapes around the areas that are most important to you economically? For this part, we'll look at both the coast and forest.

[Introduce the green discs representing economic value. The number of discs that an interviewee allocates to an area will represent relative importance/value intensity for generating income.] 
If these 100 discs represent the monetary income that you have gotten from the ocean and forests on this map over your entire career, can you allocate them on the map indicating how important each place on the map is or was to your livelihood?

If part of your income doesn't come directly from the ecosystems on this map, can you indicate with the green disks the proportion of your total income that is from outside the study area?

[If have put a substantial portion of income on ecosystems:]

Would restricting access to the resources in these locations (e.g. hunting, logging, collecting) change the monetary value that you derive from this area? [this question often doesn't make sense - especially not with landowners]

What are the [main factors] that could most impact the things you value in the places that you've marked with the green disks? Is there anything that you think could or should be done to protect what you value in that place?

\section{Section 6- Place/Heritage}

I'd like to talk with you now not just about forest ecosystems and how we use them, but also about some possible kinds of meaning or importance that might exist over and above uses that are economic or about specific resources.

Are there places in the forest that are especially important to you, but not because of anything physical you gain from them?

Prompt: That is, these places are valuable to you because they exist?

Can you describe why they are important?

Are there places that remind you of important past events that are important to you and your community?

Can you share with me some flavor of what the experience of those places and/or your attachment to them feels like?

Feel free to use stories about your experiences in these places if that helps. These can be things specific to you or your family or community. They can be recent or historical.

\section{Section 7- Identity}

Identity is the ideas, relationships, and sense of belonging that help shape who we are - who or where we belong to, the community we are a part of and so on. In this sense, you could even say that identity is tied to physical spaces and/or the things people do within those places. 
Are there places that are important to your sense of identity?

I'd love to know more about how that works?

How would you describe, if at all, the nature of the link between places and people, as that link relates to identity?

\section{Section 8- Activity/Subsistence}

Now, let's talk about the non-physical qualities or experiences derived from doing a physical activity involving the forests.

[Repeat what they've said earlier (eg, "so you've said you hunt, fish, surf, hike, snorkel"]

Thanks. Now, some of the tangible, concrete benefits from these activities include food, income, and physical stamina.

But there might be additional benefits over and above the physical things just mentioned.

Are there other things that you think benefit you or come to you as part of these physical activities you do in the forest or ocean, things that are important but not just about what you physically receive?

Prompt: For instance, perhaps you hunt pigs, which is important for feeding your family. Do you gain anything else from hunting pigs, in addition to the food?

OK, let's think about an imaginary situation. Suppose that you could chose to either collect maile for lei, or go to the store to buy a maile lei. What would you choose? What would you be missing? Or gaining?

Prompt: Describe to me how these two activities (collecting vs. buying) are different. Why does one way of doing things matter to you more than the other?

[only ask this if really makes sense:

Are the things you're describing about any sense of well-being?

And is that sense gained or lost through doing [the activities you described].]

\section{Section 9- Spiritual}

Spiritual value of a place is difficult to define, but generally captures places that are powerful because they inspire you to be aware of forces or entities larger than yourself. This can be the basis for both negative and positive feelings including things like awe, reverence, humility, and even fear.

I know this is a personal question, but if you feel comfortable and would like to, can you speak about experiences of this kind that might be associated with this area? You can be 
as general or specific as you like about both the feeling or experience and the places you associate those experiences with.

\section{Section 10- Artistic/Ceremonial}

\section{[highly context specific: in some places things will not be considered art that would be considered art elsewhere]}

Some people associate artistic works with this place, as well as ceremonies or cultural celebrations.

Let's start with art. Has a place ever provided you with ideas or images that you think could or do inspire art or some other visual or creative form?

Now, what about ceremony? First, do you consider any ceremony to be associated with this place?

[If yes,] Does the surrounding environment contribute to, inspire or enable those ceremonies in any way?

\section{Section 11 - Educational [ecosystem contribution to learning]}

Have you ever had the experience of a place(s) — or time in the forest or on the water teaching you things?

What I mean here is the way we learn things outside of / not taught in classrooms.

... Some examples?

Are there specific places that come to mind that are important for [education, life-lessons, etc.]? Which places in particular? Be as detailed as possible in your descriptions.

\section{Section 12- Intergenerational}

Are there particular experiences associated with the forests that you hope your kids and/or kids in your community will experience?

What are those experiences and what makes them important to future generations?

Were these things important to past generations, too?

Why are these things particularly important across generations?

\section{Section 13- Mapping Non-Market Values}

These last few questions have explained what we could call "non-material" benefits from the ecosystems on this map. They are much harder usually to describe or pin down. 
Even though this is true, can you use the purple pen to outline the areas that are most important to or most associated with some of the things you've described? I mean, again, important for reasons beyond economic or material ones.

[Introduce purple discs representing non-monetary value of ES.]

Can you distribute the 100 purple discs on the map based on places you value for these reasons - again, those places that are important for the reasons we've been talking about and so not necessarily related to or dependent on personal monetary gain? Can you locate and describe places that are of particular importance to you on this map? Why are they important?

Additional possible questions, depending on fatigue and relevance:

If access to the ecosystems of this area, say the ones you've said are important for reasons other than 'material' reasons, was restricted, what kind of impact would that have on you or your community? Would that restricted access make the area more or less valuable and if so why (or why not)? How much more - a little, some, a lot?

What kinds of things or "main factors" would impact what you value in the purple shapes?

Could any actions be taken to protect what you value within the purple shapes, actions that you didn't mention in the management section? What are they?

\section{Section 15 - Threats}

Using the red pen, can you outline the areas where the resources and benefits you get from the forests are most threatened? Why is each area threatened? What are the main sources of those threats?

[Introduce red discs]

These represent threats to the benefits that you get from the ocean and forests that we've been talking about so far.

Can you allocate these 100 red discs on the map according to how threatened each place is?

Just to close, I want to make sure that I haven't missed any places that you value or that are particularly important to you?

What about other places that you haven't yet mentioned that are also threatened, again, for any reason that comes to mind?

\section{Closing}

Thanks for your time. 
That's all the questions I have for you. Do you have any questions for me?

We hope to create a resource from the information you've shared. If you have additional ideas of how to disseminate this information, please let me know.

I'll send you a copy of the confidential digitized version of your mapped responses so you can identify and I can correct any mistakes. I'll also be in touch with information about the products and results of this work.

In the meantime, if you are interested in what we do with all that you've shared, please check the website or call the number listed on the information sheet I gave to you at the beginning of the interview.

If you have released your name as connected with your answers, your name will be connected with them whenever possible.

Thank you again. 


\section{Appendix 2. Elaboration of Methods}

\section{Details on dividing survey sample along dimensions of respondent background}

To explore differences in responses based on respondent background, we created respondent groups along the four dimensions of interest (age, ethnicity, level of education, and residence time). For the three dimensions for which we had to choose a 'cut-off' point for dividing the sample, we selected a point that was socially meaningful and that divided the sample into roughly two equal groups, since similar sample sizes are preferred for the Mann-Whitney test. For age, we divided the sample between those $\leq 50$ years old, and those $>50$ years old. For education, we divided the sample between those with high school education and those with posthigh school education (community college, 4-year college, or graduate degree). For residence time, we split the sample into those who have lived in Hawai' $i$ for $\geq 65 \%$ of their lives, and those who have lived in Hawai' $i$ for $<65 \%$ of their lives. For ethnicity, we created a Hawaiian and a non-Hawaiian group. 


\section{Appendix 3. Reporting Back Performance and Process Details}

The results presented in this paper were shared with the Kona Community in January 2013, through a partnership with the Hula School Hālau o ka Hāliko. Results were shared through a locally resonant medium: a live performance comprised of hula, chanting, and original music.

See www.researchspeaks.org for in-depth multi-media information on the performance and each stage of the process used to share these research results with the Kona community. 